\title{
OVERVIEW OF WATER RESOURCES IN OWENS VALLEY, CALIFORNIA
}

By Linda S. Rogers and others

U.S. GEOLOGICAL SURVEY

Water-Resources Investigations Report 86-4357

Prepared in cooperation with the

LOS ANGELES DEPARTMENT OF WATER AND POWER

$\frac{1}{5}$ 


\section{DEPARTMENT OF THE INTERIOR \\ DONALD PAUL HODEL, Secretary \\ U.S. GEOLOGICAL SURVEY \\ Dallas L. Peck, Director}

For additional information write to:

District Chief

U.S. Geological Survey

Federal Building, Rm W-2234

2800 Cottage Way

Sacramento, CA 95825
Copies of this report may

be purchased from:

Books and Open-File

Reports Section

U.S. Geological Survey

Box 25425, Building 41

Federal Center

Denver, CO 80225 


\section{CONTENTS}

Page

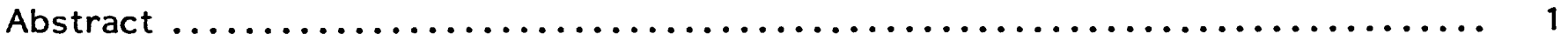

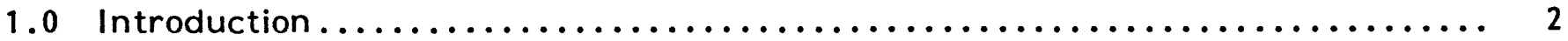

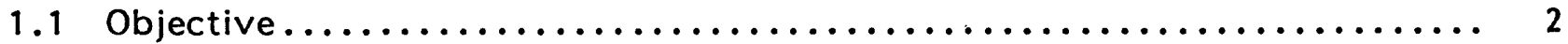

1.2 Water issues $\ldots \ldots \ldots \ldots \ldots \ldots \ldots \ldots \ldots \ldots \ldots \ldots \ldots \ldots \ldots \ldots \ldots \ldots \ldots$

Linda S. Rogers

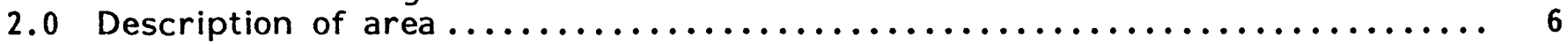

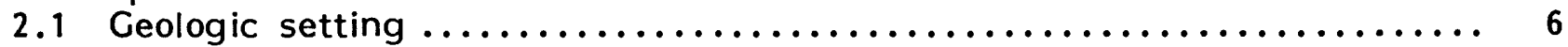

Kenneth J. Hollett

2.2 Climate....................................... 8

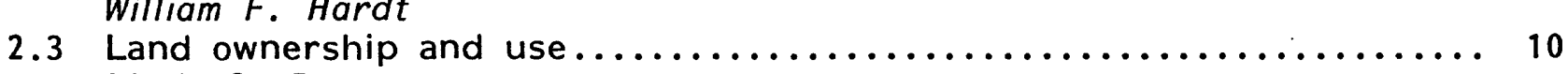

Linda S. Rogers

2.4 Native vegetation ................................... 12

Linda S. Rogers and Stephen K. Sorenson

3.0 Hydrologic budget.................................... 14

Linda S. Rogers and Kenneth J. Hollett

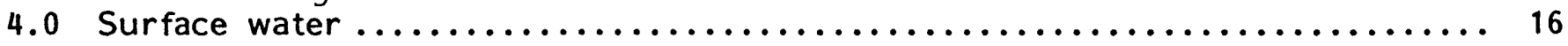

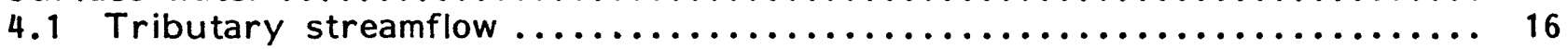

William F. Hardt

4.2 Streamflow variations $\ldots \ldots \ldots \ldots \ldots \ldots \ldots \ldots \ldots \ldots \ldots \ldots \ldots \ldots \ldots \ldots \ldots \ldots$

William F. Hardt

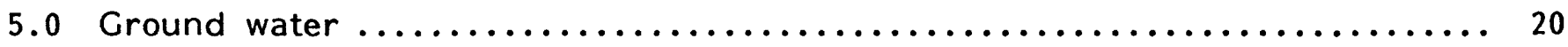

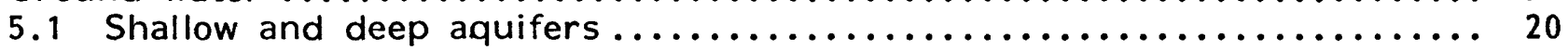

William F. Hardt and Linda S. Rogers

5.2 Recharge, discharge, and movement ..................... 22

William F. Hardt and Linda S. Rogers

5.3 Wells .......................................... 24

Linda S. Rogers

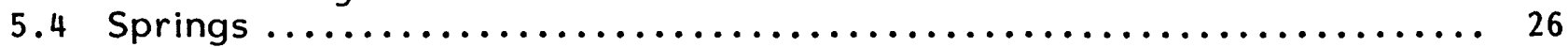

Linda S. Rogers

5.5 Aquifer response to pumpage $\ldots \ldots \ldots \ldots \ldots \ldots \ldots \ldots \ldots \ldots \ldots \ldots \ldots \ldots \ldots$

William F. Hardt and Linda S. Rogers

5.6 Historical water-level fluctuations, $1971-84 \ldots \ldots \ldots \ldots \ldots \ldots \ldots \ldots \ldots \ldots$

Kenneth J. Hollett and Linda S. Rogers

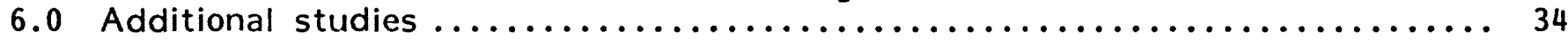

Kenneth J. Hollett

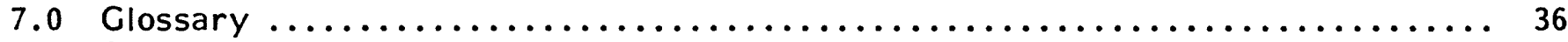

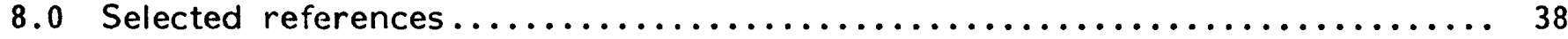




\section{CONVERSION FACTORS}

For readers who prefer to use metric units rather than inch-pound units, the conversion factors for the terms used in this report are listed below.

Multiply

acre

acre-foot

acre-foot per year

foot

foot per year

gallon

gallon per minute

inch

inch per year

mile
By

4,047

0.001233

0.001233

0.3048

0.3048

3.785

0.06308

25.40

25.40

1.609
To obtain

square meter cubic hectometer cubic hectometer per year meter

meter per year

liter

liter per second

millimeter

millimeter per year

kilometer

Air temperature is given in degrees Fahrenheit $\left({ }^{\circ} \mathrm{F}\right)$, which can be converted to degrees Celsius $\left({ }^{\circ} \mathrm{C}\right)$ by the following equation

${ }^{\circ} \mathrm{C}=\left({ }^{\circ} \mathrm{F}-32\right) / 1.8$ 


\title{
OVERVIEW OF WATER RESOURCES IN OWENS VALLEY, CALIFORNIA
}

\author{
By Linda S. Rogers and others
}

\section{ABSTRACT}

In 1982-84, a water-resources appraisal of Owens Valley was made by using available hydrologic information. $\mathrm{Re}^{-}$ sults of the appraisal provide an overview of water resources in Owens Valley; a better understanding of the groundwater system; and a framework for additional studies.

Owens Valley is in east-central California and is the major source of water supply for the city of Los Angeles, which is located 233 miles to the south. Since 1913, with the completion of the first aqueduct, surface water has been diverted from the Owens River to Los Angeles. In 1970, a second aqueduct was completed. Ground-water pumping was increased to supplement the water needed for the increasing population in Los Angeles. This increased groundwater pumping has caused concern as to whether the environment, native vegetation, and recreation in Owens Valley will be detrimentally affected.

Most of the outflow of water from Owens Valley is from exports via the aqueduct system and by evapotranspiration loss; principal sources of water are runoff, inflow from Pleasant Valley Reservoir, and precipitation. Streamflow from the Sierra Nevada is a source of tremendous quantities of water to the valley.

Pumpage from more than 90 pumpequipped wells averaged about 98,000 acre-feet per year from 1971 to 1983, but it was generally less than 10,000 acre-feet per year from 1932 to 1970 , except during dry years. The Big Pine-Crater Mountain and TabooseAberdeen well fields supply about $\mathbf{5 0}$ percent of the total pumpage in Owens Valley. Ground-water pumping is primarily from deep wells adjacent to the volcanic rocks near Big Pine. Wells completed in the volcanic rocks yield large quantities of ground water.

Water-level fluctuations in deep wells indicate a direct correlation with ground-water pumpage. There also is some correlation between pumping in deep wells and water-level fluctuations in shallow wells. Fluctuations in shallow wells, however, also are affected by changes in evapotranspiration and precipitation. The cause-and-effect relation of water-level fluctuations in deep and shallow wells is not well understood and is the subject of current studies.

In October 1982, Inyo County and the city of Los Angeles entered into agreements with the U.S. Geological Survey and with each other to conduct a 5-year study consisting of three projects: (1) vegetation, (2) plant-survivability, and (3) ground water. This multiple-agency, 5 -year study will better define the quantity and availability of ground water in the valley, as well as determine the effects of ground-water withdrawals on native vegetation. 


\title{
1.0 INTRODUCTION
}

1.1 Objective

\section{Water-Resources Appraisal of Owens Valley}

\begin{abstract}
An appraisal of available hydrologic information was done to provide an overview of water resources in Owens Valley. The location of Owens Valley and source of data are described.
\end{abstract}

An appraisal of the water resources of Owens Valley was done by the U.S. Geological Survey in cooperation with the Los Angeles Department of Water and Power. Results of the appraisal provide (1) an overview of water resources in Owens Valley, (2) a better understanding of the ground-water system, and (3) a framework for additional studies.

Owens Valley is about 200 miles north of Los Angeles in east-central California along the eastern edge of the Sierra Nevada. The valley is a long, narrow, closed basin extending from the Nevada border and Long Valley south to Haiwee Reservoir. The length of the valley is about 120 miles and the width ranges from 15 to 40 miles; the total area is 3,300 square miles. The valley is flanked by the Sierra Nevada to the west and the White and Inyo Mountains to the east. Altitudes ${ }^{1}$ range from 14,495 feet at the crest of Mount Whitney (highest in the conterminous United States) to 3,570 feet at Owens Lake (dry). The part of Owens Valley included in this study is from the Mono-Inyo County line to Haiwee Reservoir (fig. 1.1-1).
This study was done during 1982-84 and used available hydrologic information, including data collected in conjunction with the construction and operation of the Los Angeles aqueducts. Data were compiled with the assistance of Melvin L. Blevins, Gene Coufal, and Bruce W. Kuebler of the Los Angeles Department of Water and Power and Gregory James of the Inyo County Water Department.

The organization system used in the preparation of this report consists of a brief text, and accompanying maps, graphs, and tables for each of a series of water-resources-related topics. This format is particularly useful for presenting hydrologic information in a format that can be easily understood by the general public.

Because some of the hydrologic terms used in this report will be new to many readers, definitions are given in section 7.0 .

${ }^{1}$ Altitude, as used in this report, refers to the distance above the National Geodetic Vertical Datum of 1929. 


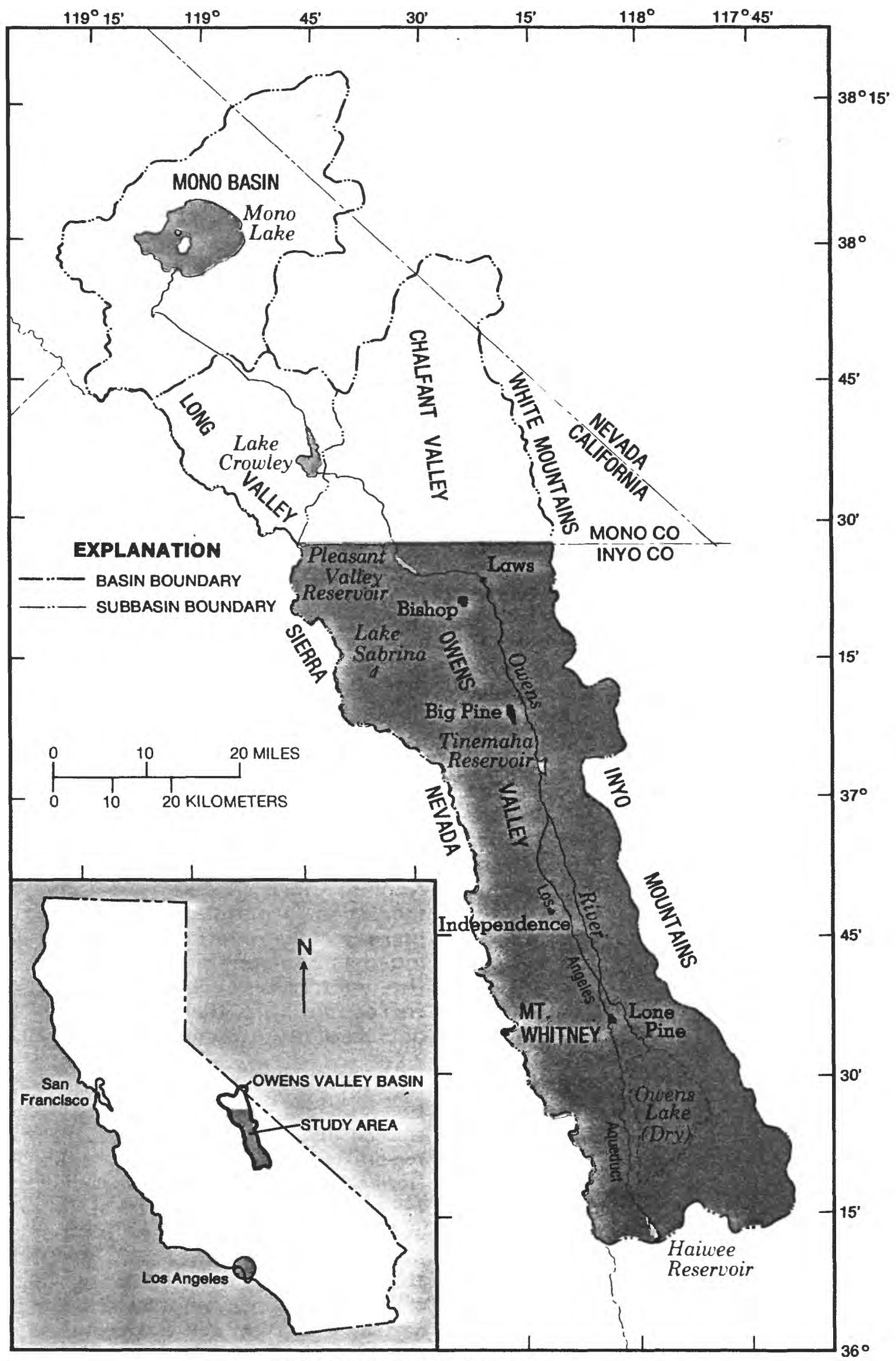

FIGURE 1.1-1.-Location of study area. 


\subsection{INTRODUCTION--Continued}

\subsection{Water Issues}

\section{Water-Availability Issues in Owens Valley}

Owens Valley in Inyo County is the major source of water supply for the city of Los Angeles; however, concern has been expressed that increased ground-water pumping may have a detrimental effect on the environment, native vegetation, and recreation in Owens Valley.

In the early 1900's, the city of Los Angeles recognized a need to develop additional water sources because of an increasing population and an inadequate local water supply. Thus, Los Angeles directed its water-gathering efforts towards Owens Valley and acquired much of the land. The first aqueduct, completed in 1913, diverted surface water from the Owens River to Los Angeles, which is located 233 miles to the south (fig. 1.2-1). During the years 1913-70, surface-water diversions were supplemented by modest quantities (generally less than 10,000 acre-feet per year) of ground water. In 1970, a second aqueduct was completed (figs. 1.2-1 and 1.2-2), which increased the average capacity for exporting water by 50 percent. With the completion of the second aqueduct, ground-water pumping was increased to supplement the water needed for the increasing population in Los Angeles.

Water from Owens River is diverted into the Los Angeles Aqueducts about 5 miles south of Tinemaha Reservoir. The reservoir (storage capacity, 16,405 acrefeet) regulates flow of the river prior to diversion. In addition, ground water from pump-equipped wells is delivered to the aqueduct system throughout the valley. The total quantity of surface water and ground water exported is measured at Haiwee Reservoir, about 8 miles south of Owens Lake. From this reservoir, water flows by gravity in the aqueduct to Los Angeles.
Water exports to Los Angeles increased from about 150,000 acre-feet in 1925 to 500,000 acre-feet in 1982 (fig. 1.2-3) Los Angeles Department of Water and Power, 1979, fig. A-1). The average quantity of water exported was

\begin{tabular}{cc}
\hline $\begin{array}{c}\text { 10-year } \\
\text { averages } \\
\text { (calendar } \\
\text { year) }\end{array}$ & $\begin{array}{c}\text { Water } \\
\text { exports } \\
\text { (acre-feet } \\
\text { per year) }\end{array}$ \\
\hline $1940-49$ & 294,700 \\
$1950-59$ & 332,100 \\
$1960-69$ & 347,800 \\
$1970-79$ & 454,400 \\
\hline
\end{tabular}

The increase in water exports to Los Angeles since 1970 is partly the result of increased ground-water pumping. This increased long-term ground-water pumping has caused concern as to whether the environment, native vegetation, and recreation in Owens Valley will be detrimentally affected.

Water-management issues relating to the second aqueduct have been the source of controversy and litigation between Inyo County and the Los Angeles Department of Water and Power. In 1972. Inyo County filed a lawsuit and obtained a temporary injunction that limited the quantity of ground water that could be pumped until the effects of increased pumping on the environment of Owens Valley are evaluated. 

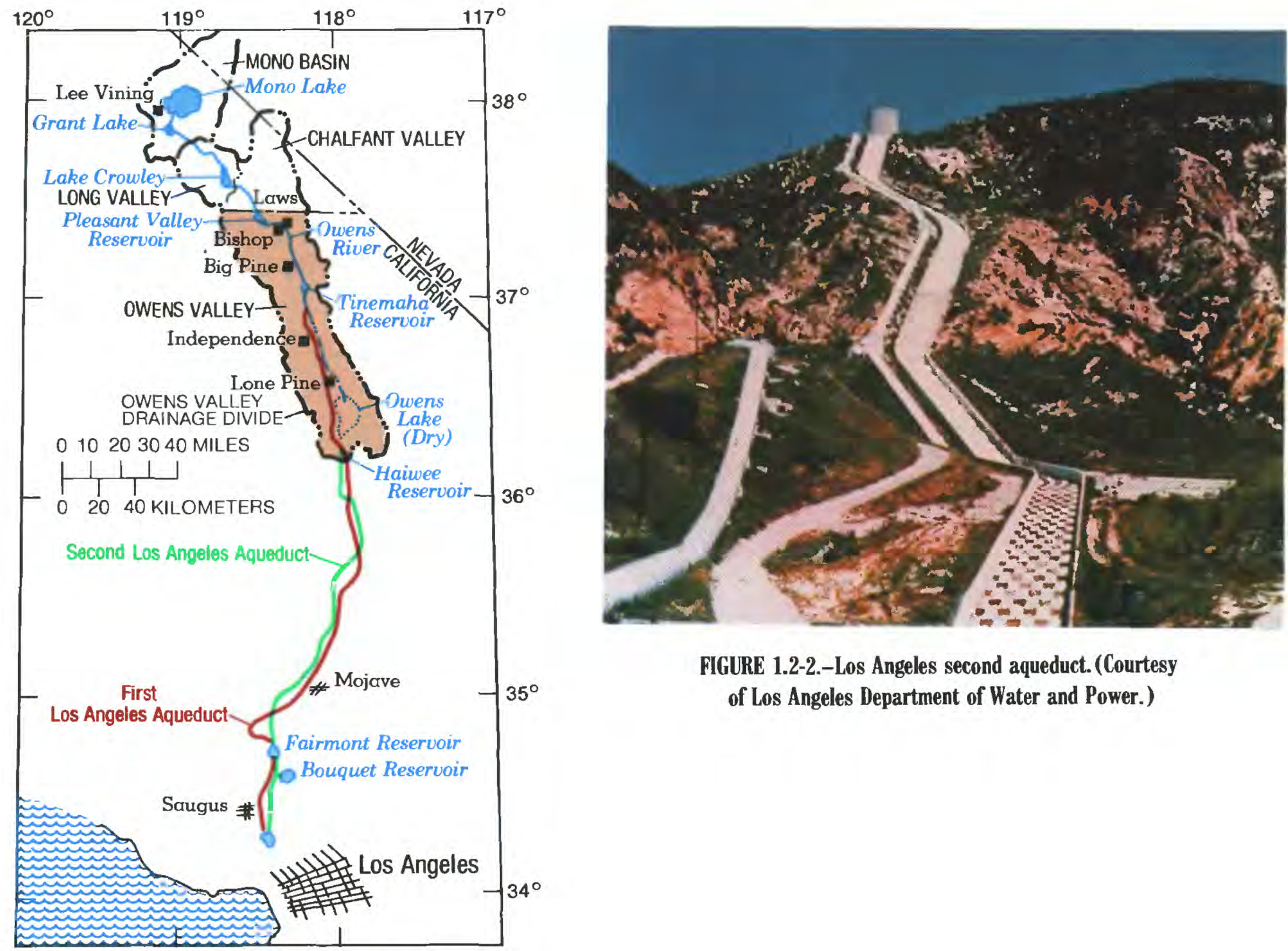

FIGURE 1.2-2.-Los Angeles second aqueduct. (Courtesy of Los Angeles Department of Water and Power.)

FIGURE 1.2-1.-Location of first and second aqueducts.

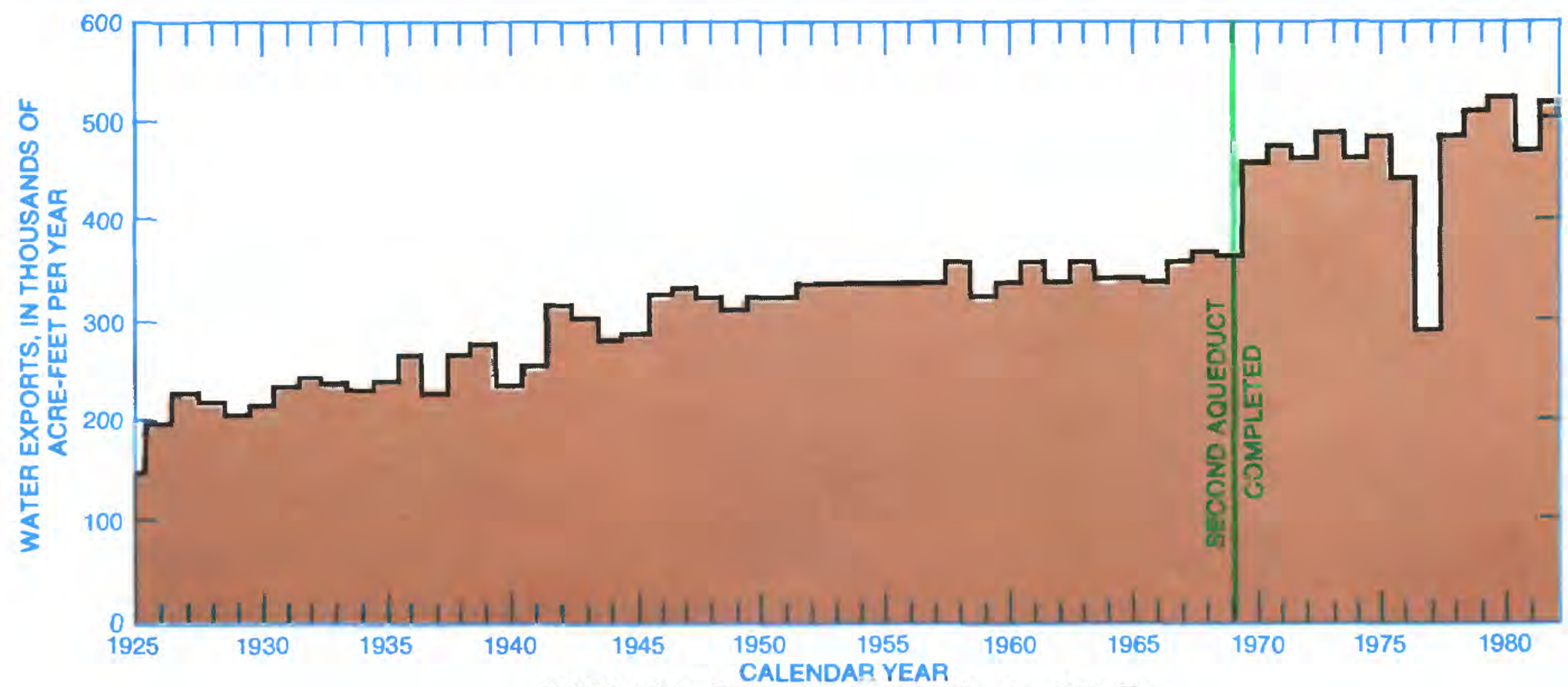

FIGURE 1.2-3.-Water exported to Los Angeles, 1925-82.

(Los Angeles Department of Water and Power, 1979, Fig. A-1.) 


\title{
2.0 DESCRIPTION OF AREA
}

\subsection{Geologic Setting}

\section{Geologic Features are Complex and Diverse}

\author{
Owens Valley is a down-dropped block fault between the White and Inyo Mountains \\ and the Sierra Nevada.
}

Owens Valley is a long, narrow, sediment-filled trough that has been dropped down (as a graben) along normal faults that separate the valley from the Sierra Nevada and the White and Inyo Mountains. The sides and bottom of the valley are formed by non-waterbearing granitic, sedimentary, and metamorphic rocks. Thin layers of glacial deposits, eroded from the mountains during glacial periods that occurred 10,000 to 2 million years ago, are found in many of the mountain passes and valleys of the Sierra Nevada. The generalized geology of the Owens Valley area is shown in figure 2.1-1.

The valley is filled with unconsolidated to moderately consolidated valley-fill deposits, overlain by and interbedded with volcanic ash and flows. Most of the valley-fill deposits consist of gravel, sand, silt, and clay that were eroded from the surrounding mountains. Alluvial fans, the buildup of alluvial deposits along the west side of the valley and to a lesser extent along the east side, represent the most recently eroded material from the Sierra Nevada, and the White and Inyo Mountains. The valleyfill deposits along the center of the valley range in depth from less than 1,000 feet to more than 8,000 feet.

Most of the volcanic rocks crop out in the Tableland north of Bishop and in mid-valley near Big Pine. Volcanic rocks that compose the Tableland generally are ash and pumice material which overlies older, moderately consolidated valley-fill deposits. The Tableland volcanic rocks are an extension of the older volcanic rocks that resulted from eruptions in the Long Valley area. Volcanic rocks that crop out near Big Pine are composed mostly of layered lava flows and cinder cones. Many of the lava flows are interbedded with and covered by valley-fill deposits.

Lakebed deposits of silt and clay are exposed at the surface in Owens Lake (dry) and other smaller playa areas in the valley. Numerous, and at times horizontally continuous, lenses of these lakebed deposits are interlayered in the subsurface with coarser-grained deposits, giving the valley-fill deposits a layered, alternating coarse- to finegrained structure.

Faults, which laterally and vertically offset adjacent rocks and valley-fill deposits, generally trend northwest to southeast in the valley. Major vertical faults buried along the valley margin form the edges of the valley and define the lateral extent of the valley-fill deposits. Some faults that cut the valley-fill deposits create a stepped, layered structure in the deposits. 


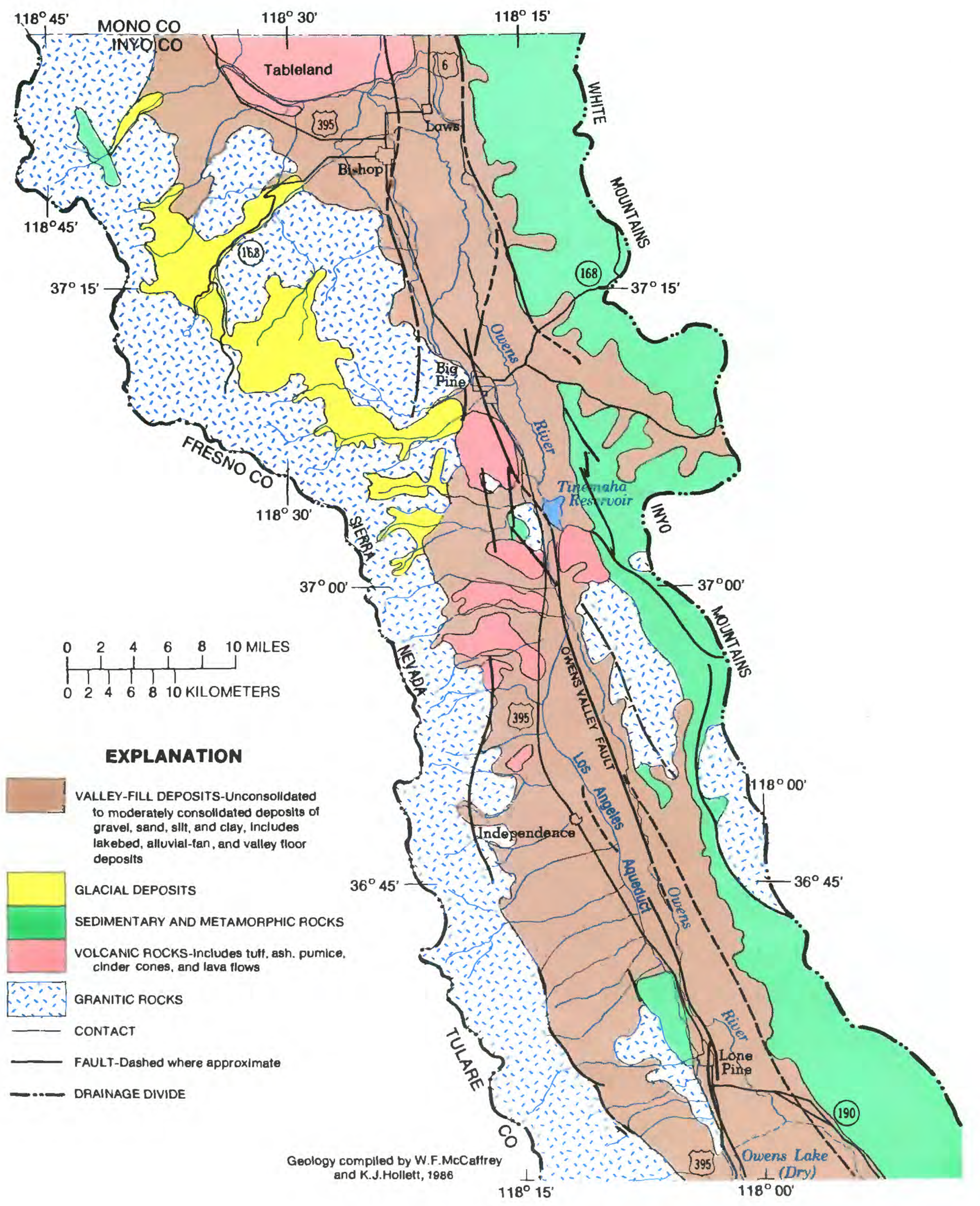

FIGURE 2.1-1.-Generalized geology of the 0wens Valley area. 


\title{
2.0 DESCRIPTION OF AREA--Continued
}

\subsection{Climate}

\section{Precipitation and Temperatures Vary in the Mountains and on the Valley Floor}

\begin{abstract}
Most precipitation occurs between November and March, with the Sierra Nevada receiving 3 to 8 times more precipitation per year than the valley floor.
\end{abstract}

Owens Valley has an arid climate, which is affected by the rainshadow effect of the Sierra Nevada. Moisture moving eastward in the form of clouds must rise above the Sierra Nevada, resulting in most precipitation falling in the higher altitudes west of the valley in the Sierra Nevada. Smaller quantities of precipitation fall along the east side in the White and Inyo Mountains and on the central part of the valley floor. Generally, about two-thirds of the precipitation occurs between November and March. During the summer, thundershowers can result in high-intensity short-term precipitation, but they add little to the ground-water supply because of rapid runoff and high evaporation losses.

Annual records indicate that the mountains receive 3 to 8 times more precipitation than the valley floor. Also, precipitation varies greatly from year to year--by a factor of as much as 4 in the mountains and by a factor of as much as 19 on the valley floor. Precipitation data for two representative climatic areas are shown in figure 2.2-1.

Air temperatures in Owens Valley are extreme and range from more than $100^{\circ} \mathrm{F}$ in the summer to less than $0^{\circ} \mathrm{F}$ in the winter. Summer temperatures are accompanied by large evapotranspiration rates. As shown in figure 2.2-2, potential evapotranspiration during July at Bishop Airport averages about 6 inches. Evapotranspiration depends heavily on climatic factors such as wind velocity, temperatures, radiation from the sun, and relative humidity, as well as soil moisture and the type and density of vegetation cover. 


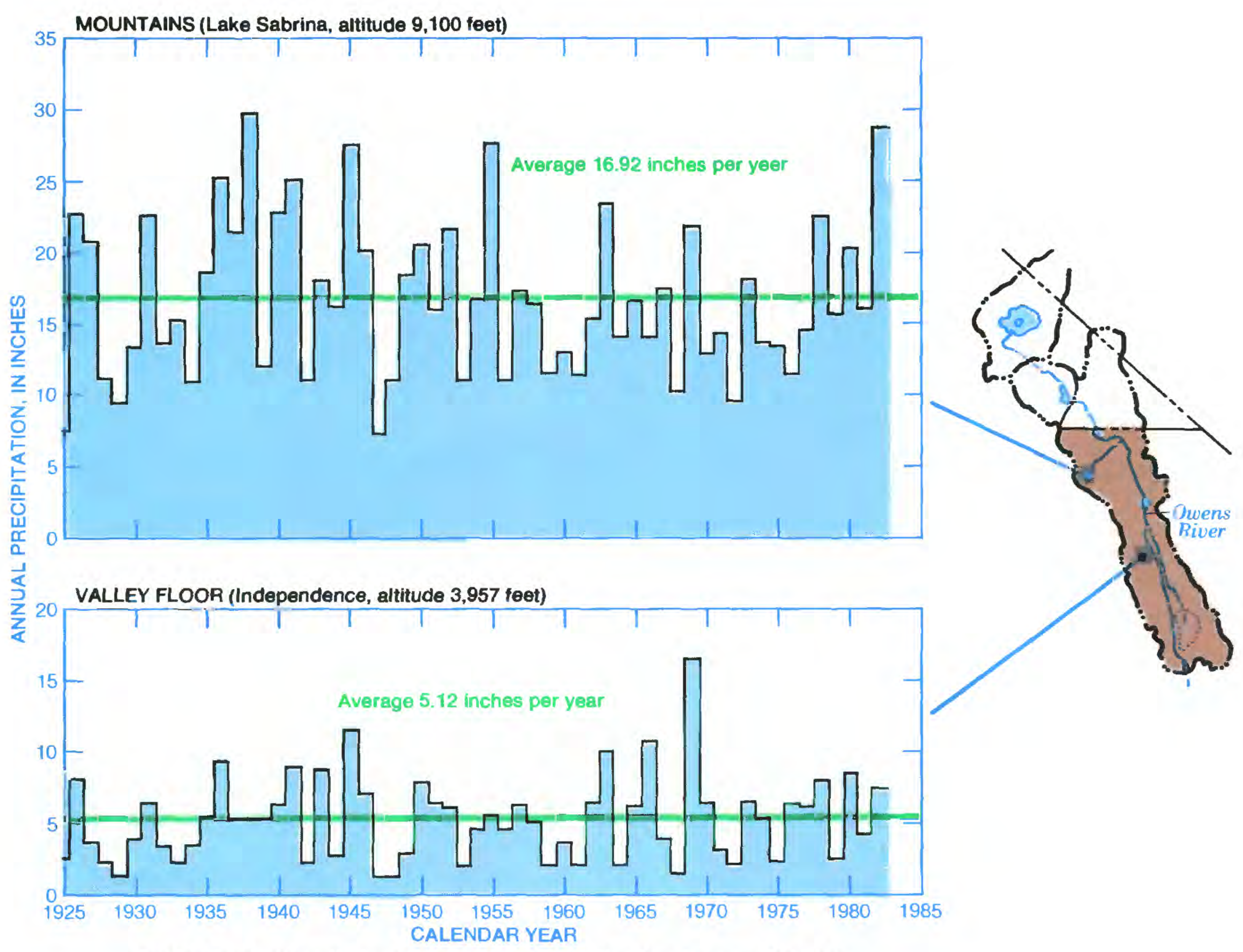

FIGURE 2.2-1.-Precipitation data for two representative climatic areas, 1925-82.

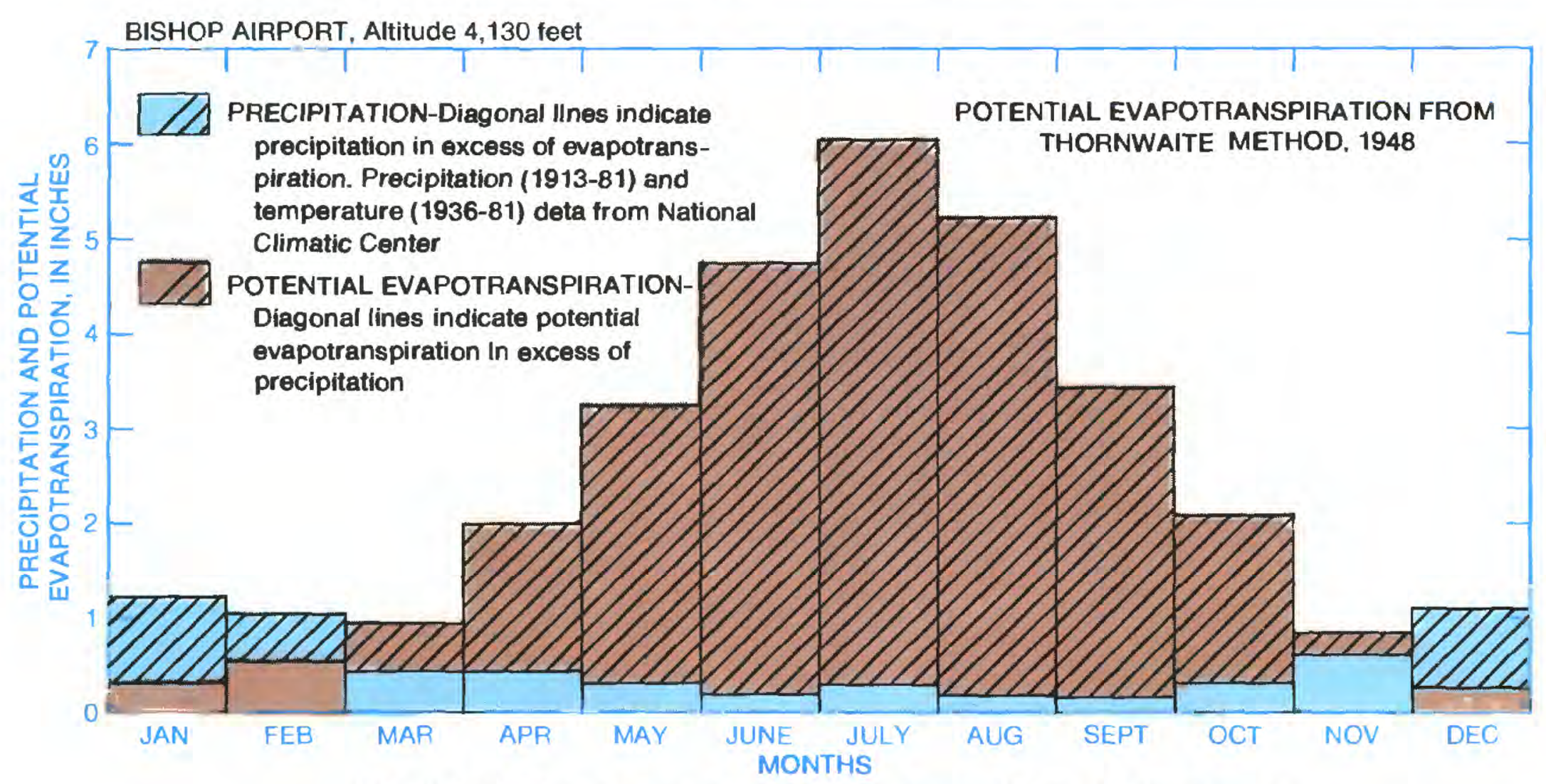

FIGURE 2.2-2.-Potential evapotranspiration and precipitation at Bishop Airport.

\subsection{DESCRIPTION OF AREA - - Continued




\subsection{DESCRIPTION OF AREA--Continued}

2.3 Land Ownership and Use

\section{Land Ownership and Use Described}

The Federal Government and the city of Los Angeles are the major landowners. Ranching is the predominant land use.

The predominant land use in Owens Valley is ranching. Most of the valley floor is used as rangeland for cattle and other livestock (fig. 2.3-1). Land use on the valley floor is limited mainly to cattle grazing, alfalfa production, and recreation. Recreational use of 150,000 acres of scenic land, including hunting. fishing, and other outdoor sports, is the major economic activity in Owens Valley (fig. 2.3-2).

Land ownership is divided principally between the Federal Government and the city of Los Angeles. Only a relatively small amount of land is held in private ownership. The mountains and steep slopes, both on the east and west side of the Owens Valley, are part of the Inyo National Forest. Slope areas along the valley margin are owned by the U.S. Bureau of Land Management. In general, City-owned lands are located on the valley floor from north of Bishop to south of Lone Pine (fig. 2.3-3). There are small pockets of private land scattered throughout the Owens Valley: however, the major private holdings are located within and adjacent to the municipalities of Bishop. Big Pine, Independence, and Lone Pine (Los Angeles Department of Water and Power, 1979). 


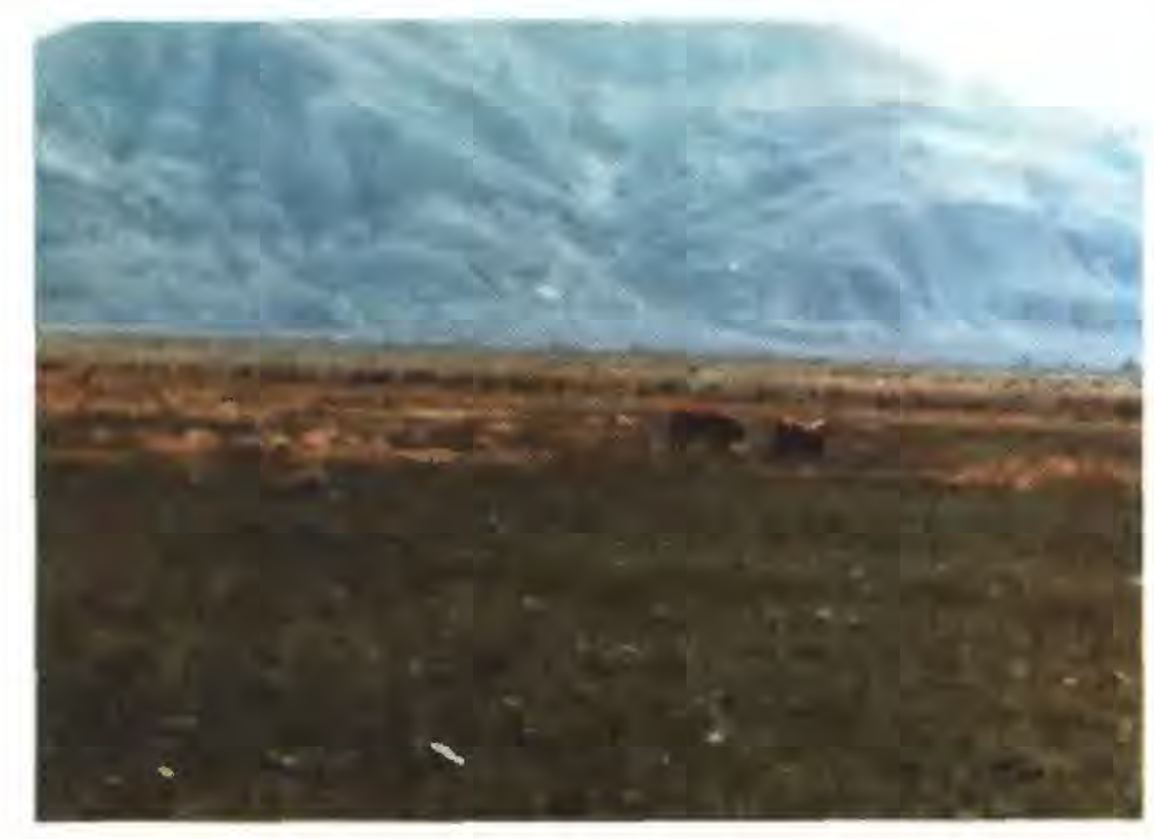

FIGURE 2.3-1.-Cattle grazing.

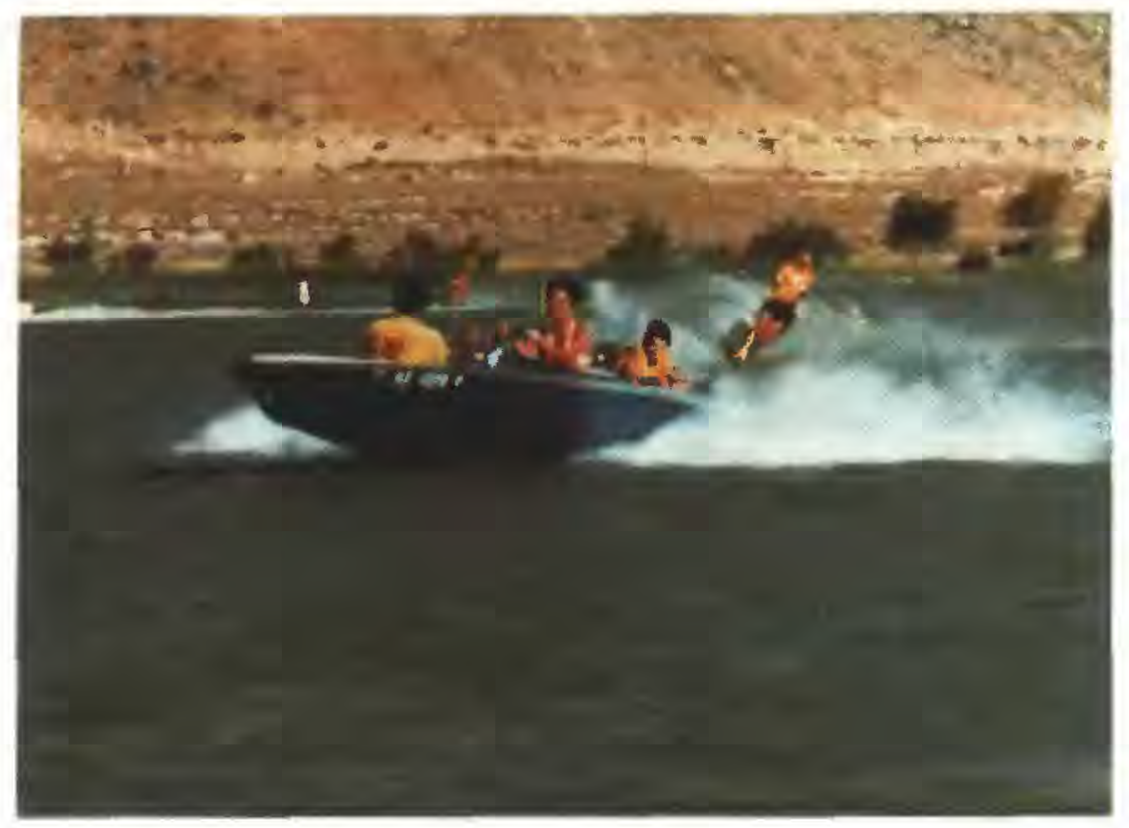

FIGURE 2.3-2.- Recreation.

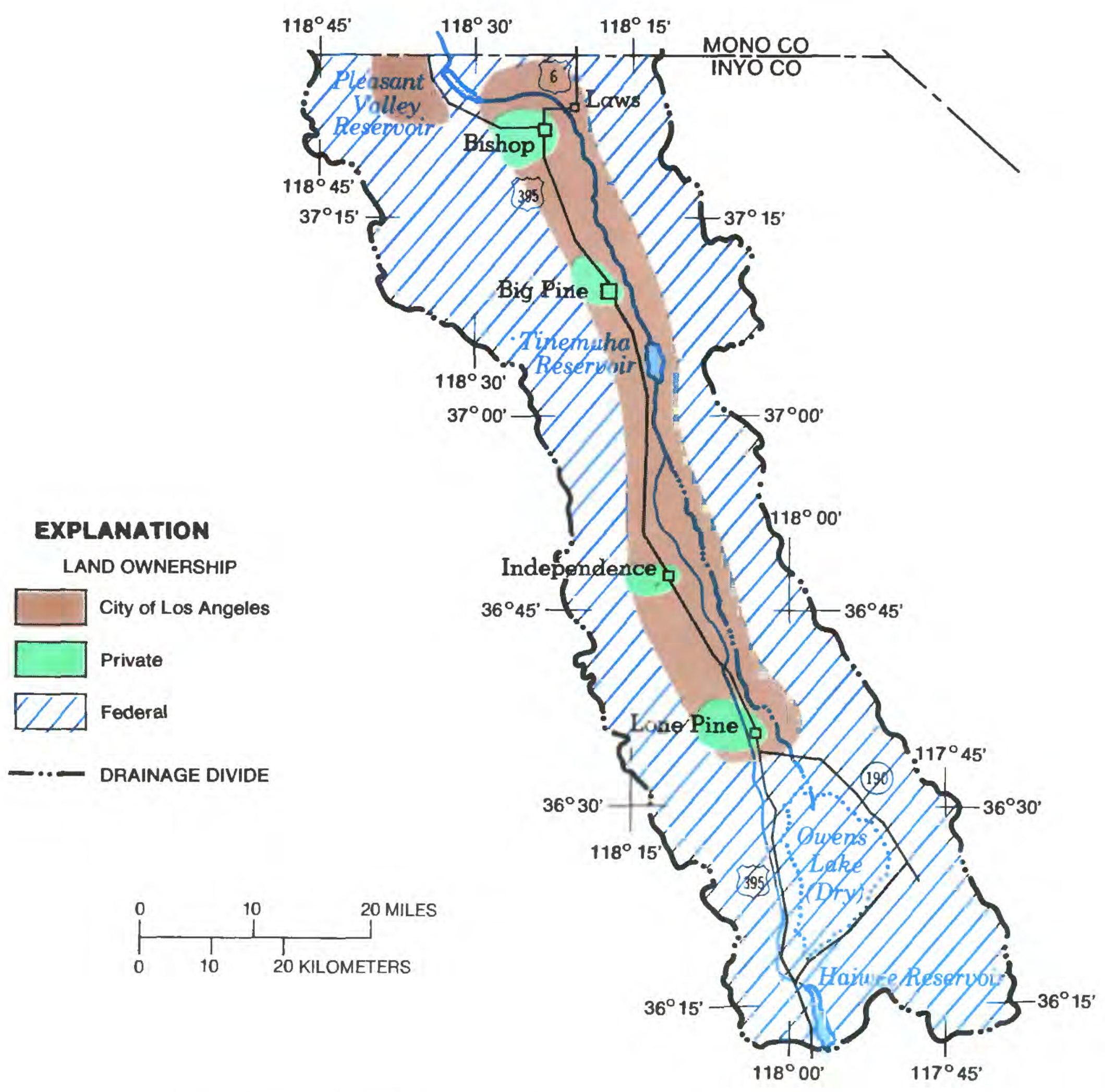

FIGURE 2.3-3.-Land ownership. (Adapted from Hardt, 1980.) 


\title{
2.0 DESCRIPTION OF AREA--Continued
}

2.4 Native Vegetation

\section{Vegetation Communities Described}

\begin{abstract}
Vegetation is of primary interest because of concern that it could be affected by continued increased ground-water pumping.
\end{abstract}

Most of the land in Owens Valley is covered by native vegetation. Vegetation in the Owens Valley consists of more than 2,000 species and almost infinite variations within the species (Bateman and others, 1978). Plant species grow together because of shared tolerances or preferences to the selecting influences of soil, water, and climate. Combinations of soil, $\mathrm{pH}$, salinity, and texture combined with ground- or surface-water availability have established patterns of vegetation growth. Within the valley. there are nine recognized vegetation communities (Griepentrog and Groeneveld, 1981).

Within the valley, the native vegetation communities that occupy the greatest land area are (1) high ground water alkaline meadow, (2) high ground water alkaline scrub, (3) dryland alkaline scrub, and (4) dryland nonalkaline scrub (Griepentrog and Groenveld, 1981. p. 29). Each of these vegetation communities have preference for different soil types and water availability. Each of these communities have certain indicator plants which distinguish it. Below is a description of each of the vegetation communities. The plant species shown are indicator species useful for recognizing the four largest communities (Griepentrog and Groeneveld, 1981).
(1) High ground water alkaline meadow-highly salt tolerant vegetation growing on permanently or seasonally moist soils. Distichlis spicata--Saltgrass (fig. 2.4-1).

(2) High ground water alkaline scrub--a salt and alkalinity tolerant shrubs requiring connection to ground water and often occurring on very fine soils. Atriplex torreyi--Nevada Saltbush (fig. 2.4-2).

(3) Dryland alkaline scrub--A vegetation community on well drained and often alkaline or saline soils depending on the location within the valley. Atriplex confertifolia--Shadscale (fig. 2.4-3).

(4) Dryland non-alkaline scrub community--This vegetation community varies according to its location relative to the base of the Sierra Nevada. In general, this vegetation is intolerant of high salinity and alkalinity and requires coarse, well-drained soils. Artemisia tridentata--Big Sagebrush (fig. 2.4-4).

The vegetation on the Owens Valley floor is of primary interest because it could be affected by continued increased ground-water pumping. The high ground-water communities are the vegetation most affected by water-table declines. 


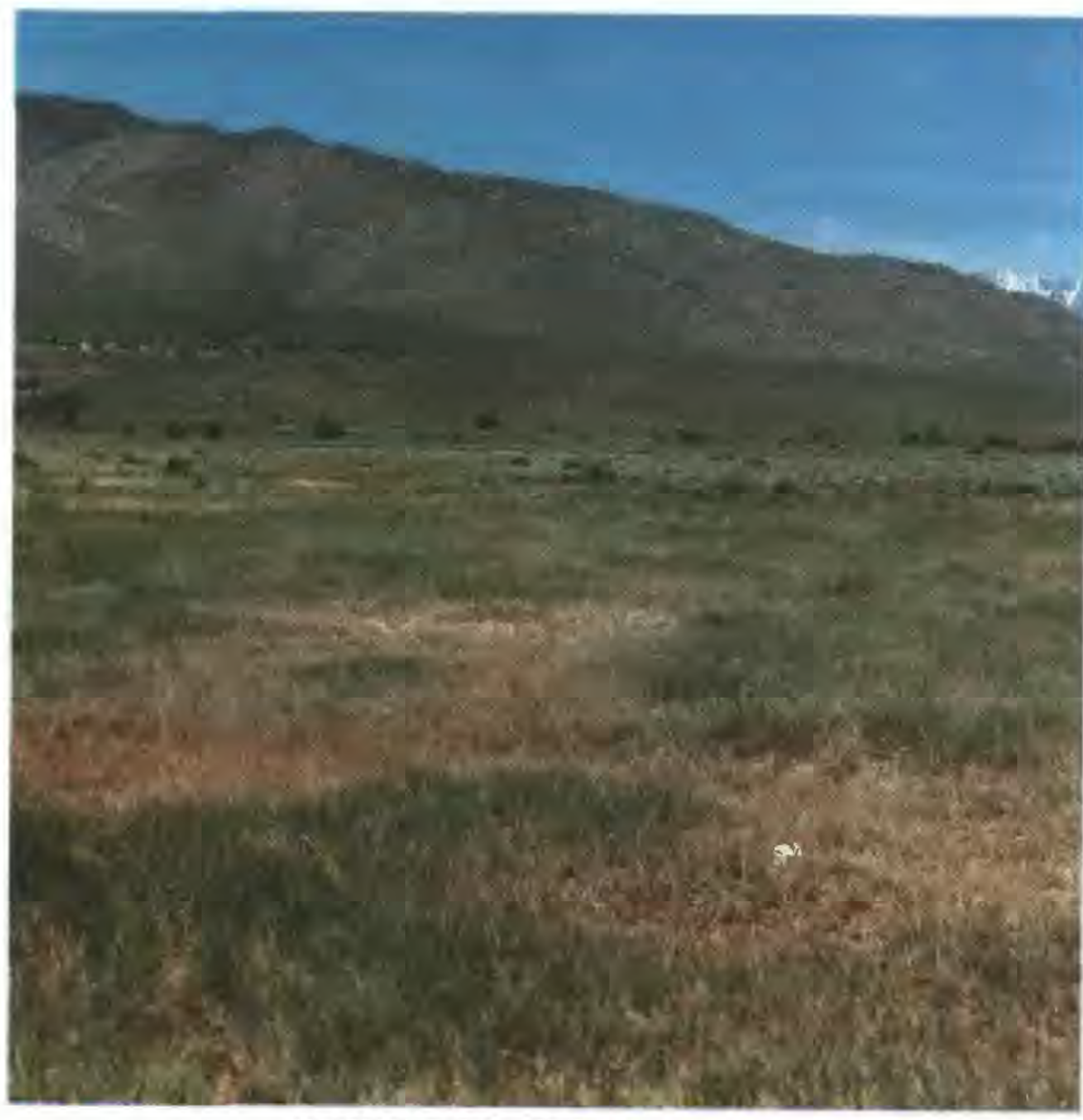

FIGURE 2.4-1.-Saltgrass.

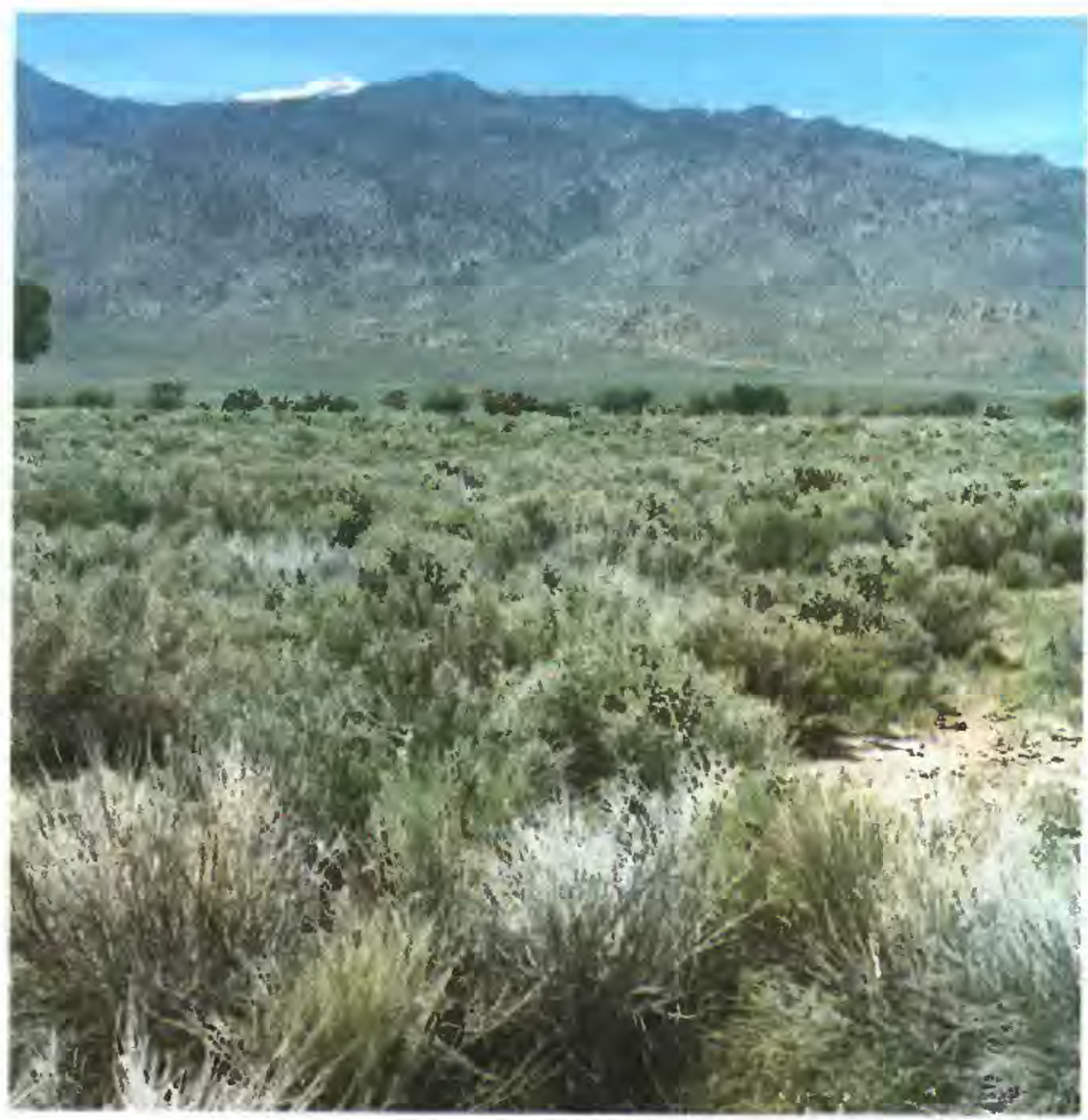

FIGURE 2.4-2.-Nevada Saltbush.

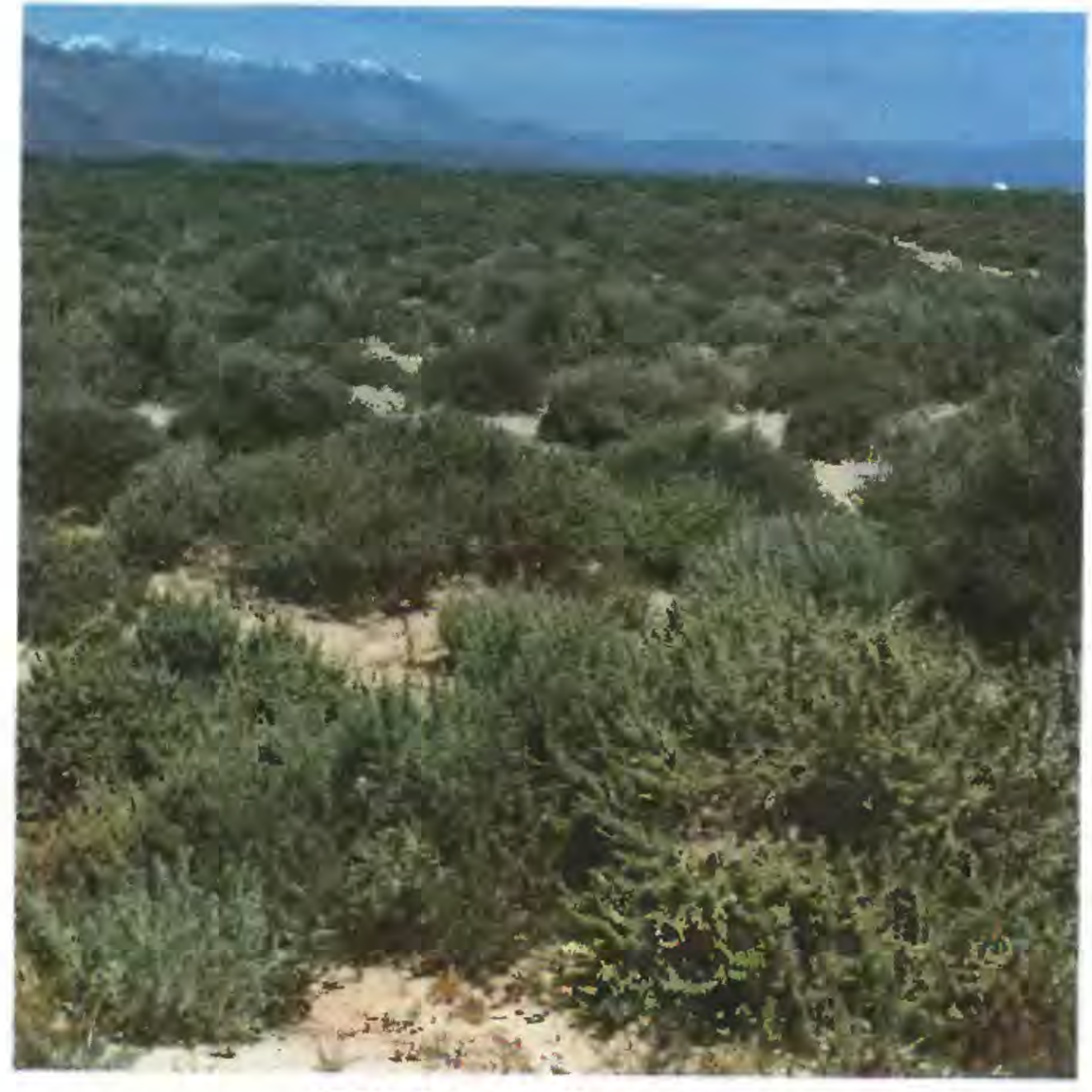

FIGURE 2.4-3.-Shadscale.

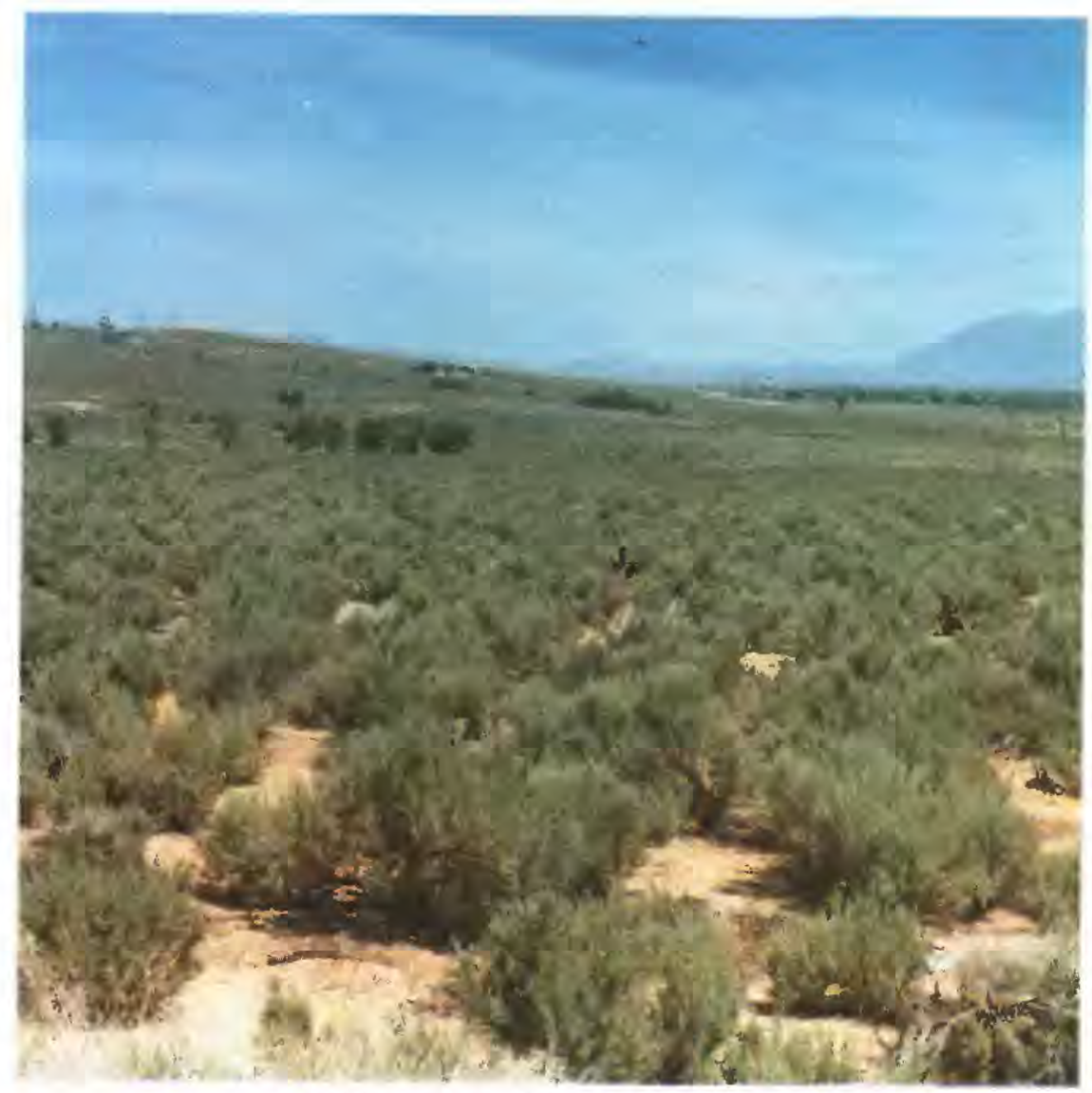

FIGURE 2.4-4.-Big Sagebrush.

\subsection{DESCRIPTION OF AREA--Continued




\title{
Evapotranspiration and Water Exports are Large
}

\begin{abstract}
Most of the outflow of water is from exports and by evapotranspiration loss; principal sources of water are runoff, inflow, and precipitation.
\end{abstract}

A hydrologic budget is an accounting of inflows, outflows, and changes in storage in the valley's hydrologic system (combined surface and ground water). Water in storage is the quantity of water in aquifers and surface reservoirs. In estimating this hydrologic budget, changes in storage are assumed to be zero. Percentages and totals of inflow and outflow shown in figure $3.0-1$ were estimated using data from Los Angeles Department of Water and Power (1979. table D1-9) and represent the average annual conditions for 1971-83.

Primary inflows of water to Owens Valley hydrologic system are runoff along the mountain fronts, surface-water inflow at Pleasant Valley Reservoir, precipitation on the valley floor, and groundwater inflow from Chalfant Valley, Round Valley, and the Volcanic Tablelands (fig. 3.0-1). Inflow via the Owens River to Pleasant Valley Reservoir represents mountain runoff from the Long Valley and Mammoth areas and surface-water diversions from Mono Basin. Streamflow from the tributaries that drain the Sierra Nevada is a source of tremendous quantities of water to the valley. Some of the streamflow recharges the groundwater system, but most is captured in the Owens River, Los Angeles Aqueduct, or canals, spreading, or release areas.

Primary outflows in Owens Valley are from transpiration by native vegetation and irrigated lands, evaporation from soil and open-water surfaces, and exports to Los Angeles (fig. 3.0-1). Evapotranspiration depends on types of irrigated lands or native plants, percentage of plant cover versus bare soil. and climatic factors such as wind velocity, temperatures, radiation from the sun, and relative humidity. Nearly all of the precipitation that falls on the valley floor is transpired by plants or evaporated before it infiltrates to the ground-water system.

The ground-water system, as a part of the hydrologic system, functions as a storage and transportation medium. Water enters the ground-water system as recharge and is discharged by pumpage, flowing wells, springs, seepage to rivers, underflow beneath Haiwee Reservoir, evaporation, or transpiration by plants. Pumpage is used to supplement export of water and to supply in-valley use, such as municipal water systems, irrigation, and fish hatcheries. The small amount of water from flowing wells, springs, and seepage is combined with streamflow for export. Most of the water that recharges, but not held in storage, passes through the groundwater system and is eventually transpired by plants, evaporated, or exported. Only about 1 percent of the water flows out of the valley as underflow beneath Haiwee Reservoir. 

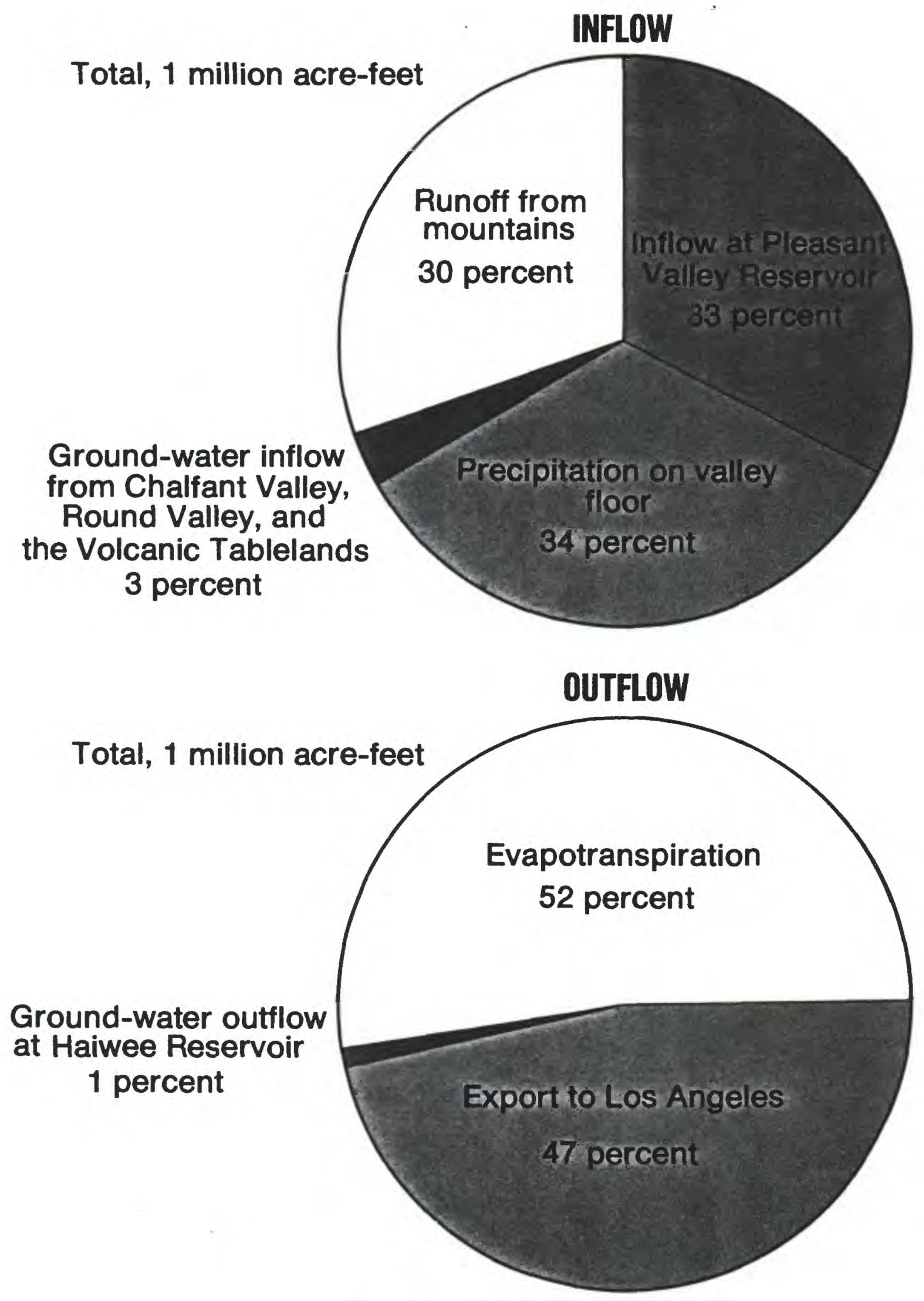

FIGURE 3.0-1.-Hydrologic budget, 1971-83. 


\title{
4.0 SURFACE WATER
}

4.1 Tributary Streamflow

\section{Streamflow is Measured at 34 Sites}

\begin{abstract}
Runoff from the Sierra Nevada contributes most of the streamflow to the valley. Streamflow is measured as inflow from 34 gaged tributaries originating in the Sierra Nevada.
\end{abstract}

The source of most of the water supply to the Owens Valley is surface runoff in streams that originate in the Sierra Nevada and precipitation that falls directly on the valley floor. Runoff occurs largely from the melting snowpack during the spring and early summer. The Sierra Nevada drainage area borders the west side of Owens and Long Valleys and the south side of nearby Mono basin. Streamflow from tributaries in the White and Inyo Mountains, along the east side of the valley, is small.

Much of the runoff from numerous streams that drain the Sierra Nevada flows downstream to the Owens River and the Los Angeles Aqueduct and then to Haiwee Reservoir. Tributary streamflow above Tinemaha Reservoir drains to the Owens River where it remains in the natural channel until diverted to the aqueduct-intake south of Tinemaha Reservoir. Below the intake, tributary streamflow drains directly into the aqueduct.
Most of the tributary streams that drain the Sierra Nevada are less than 10 miles in length and flow at gradients of 100 feet per mile toward the Owens River. The Owens River is the principal stream in the valley. All the tributary streamflow, however, does not reach the Owens River because of upstream diversions into canals and ditches, including the Los Angeles Aqueduct. Also, some surface water recharges the groundwater system or is diverted to nearby pasture and alfalfa lands.

Streamflow into the valley is measured at gaged sites on 34 tributaries (fig. 4.1-1). The Owens River gage at Pleasant Valley Reservoir $(10$ miles northwest of Bishop [site 1]) measures the streamflow into the central part of the valley that originates as runoff from upstream areas, including Long ValleyMammoth area and Mono basin. The five streams that contribute the most inflow are Owens River (site 1), and Bishop (site 4), Big Pine (site 10), Cottonwood (site 32), and Independence (site 21) Creeks. 


\section{EXPLANATION}

SITE NUMBERS AND TRIBUTARY NAMES

1. Owens River at Pleasent Valley Reservolr

2. Hortan Creek

3. MeGee, Birch, and Coyote Creaks

4. Bishop Crook

5. Anwson Creek

6. Coldwater Canyon Crook

7. Silver Canyon Creak

8. Fish Slough

9. Baker Croek

10. Big Pine Croek

11. Birch Croek

12. Tinemaha Creek

13. Red Mountain Creak

14. Taboose Creek

15. Goodale Creok

16. Division Creek

17. Sawmill Creok

18. Thibaut Creak

19. Dak Creak (North Fork)

20. Dak Croek (South Fork)

21. Independence Creek

22. Symmes Creak

23. Shapherd Creek

24. Bairs Creek (North Fork)

25. Bairs Creek (South Fork)

20. George Creek

27. Hogback Creok

20. Lone Pine Creok

29. Tuttlo Creek

30. Lubkin Creak

31. Carroll Creak

32. Cottonwood Croek

33. Ash Creok

34. Braley Creek

FIGURE 4.1-1.-Location of tributaries.

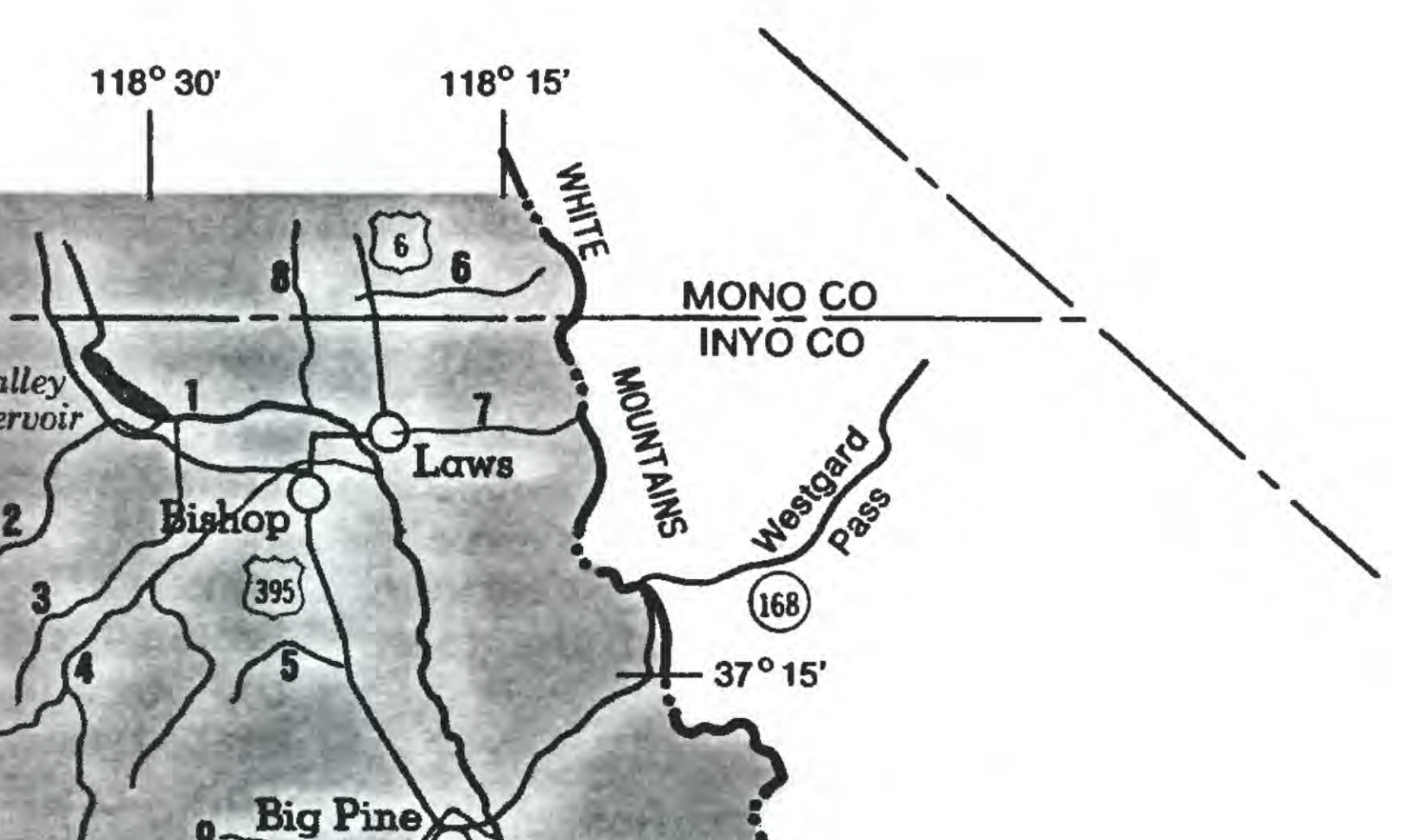




\subsection{SURFACE WATER--Continued}

4.2 Streamflow Variations

\section{Streamflow Varies Markedly}

Records of annual streamflow for 34 tributaries illustrate the magnitude and
variability of the water-supply potential for Owens Valley.

The largest tributary in the valley is the Owens River. The river's average flow of 277,067 acre-feet per year (1945-81) into Pleasant Valley Reservoir (site 1), is about 53 percent of the total measured streamflow.

The maximum annual streamflow during 1935-81 occurred in 74 percent of the streams in 1969. In early 1969, greater than average precipitation throughout California caused extensive flooding. Minimum annual flows occurred in 29 percent of the streams in 1961 and in 18 percent of the streams in 1960 and 1977. Thus, about 47 percent of the streams had minimum flow during the droughts of 1959-61.
Total average streamflow in the Owens Valley was 521,559 acre-feet per year for 1935-81. The total of the maximum annual flows at all the gaged sites in table $4.2-1$ is 322 percent larger than the total of the minimum annual flows that have occurred at the same sites. This comparison is slightly misleading as an example of flow variability in that all the maximum and minimum flows did not occur in the same year. The maximum total annual inflow to the valley probably occurred in 1969, and would have to be less than the total of 924,072 acre-feet shown in table 4.2-1. Likewise, the minimum total annual flow, which occurred in 1977, would have been slightly larger than the total of 286,384 acre-feet shown in table 4.2-1. The 1969 total inflow was 280 percent of the 1977 total inflow. 
Table 4.2-1.--Streamflow data

[Average flow: Water years 1935-81]

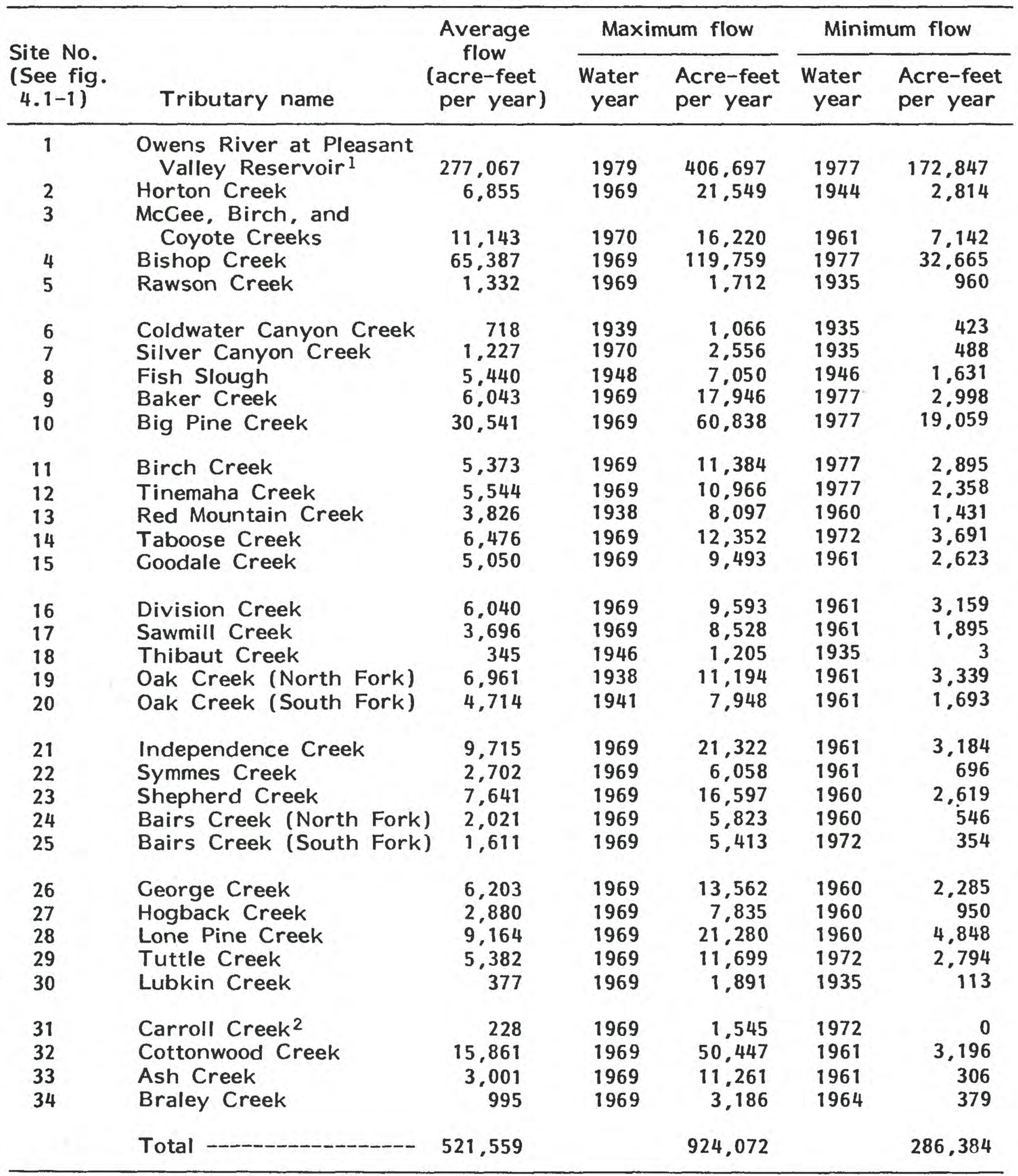

1 Period of record, 1945-81.

2Site 31 has been dry for 14 different years, the latest year is shown. 


\title{
5.0 GROUND WA'TER
}

5.1 Shallow and Deep Aquifers

\section{Aquifers Consisting of Valley-Fill Deposits and Volcanic Rocks Yield Large Quantities of Water}

\begin{abstract}
The saturated valley-fill deposits are generally divided into shallow and deep aquifers owing to the presence of extensive clay layers.
\end{abstract}

Because of the depositional history of the Owens Valley, the valley-fill deposits range from clay, which has a low ability to transmit water, to sand and gravel. which readily transmit large quantities of water. The water-bearing valley-fill deposits are separated, to varying extent, by many confining layers of clay (see fig. 5.1-1, wells 248 and 292). Where these layers of clay are sufficiently thick and reasonably continuous, the valley-fill deposits are separated into two or more aquifers. The shallow aquifer is an unconfined system above the clay layer. The deep aquifers are below and separated from the shallow aquifer by clay layers. The deep aquifers generally are under pressure due to restriction of vertical flow caused by clay layers. In such cases, the aquifer is considered to be confined.

Six drillers' logs were selected from more than 250 drillers' logs available for wells throughout the valley (fig. 5.1-1). These data represent the interval between land surface and depths of less than 1,000 feet. These logs show the variation of type, distribution, and thickness of the sediments. Logs that represent wells completed in the valleyfill deposits (fig. 5.1-1, wells 68 and 346) indicate that layers of gravel, sand, and clay are not continuous or at the same depth throughout the valley. Drillers' logs that represent wells drilled only a short distance apart may indicate markedly different distribution and thickness of clay layers versus sand and gravel layers.

- Volcanic rocks also are important aquifers in the valley. The logs that represent wells drilled in the volcanic rock are similar, showing "broken black rock" (fig. 5.1-1, wells 219 and 355). The extent and location of the volcanic rocks in the subsurface is generally associated with the occurrence of volcanic rocks found at the surface. The volcanic rocks are fractured and wells drilled into these rocks generally yield as much as 9,000 gallons per minute of water. 
[Altitude (Alt.) is land-surface altitude, in feet above National. Ceodetic Vertical Datum of 1929. Thickness of material is in feet. Depth to bottom of material, is in feet below land surfacel

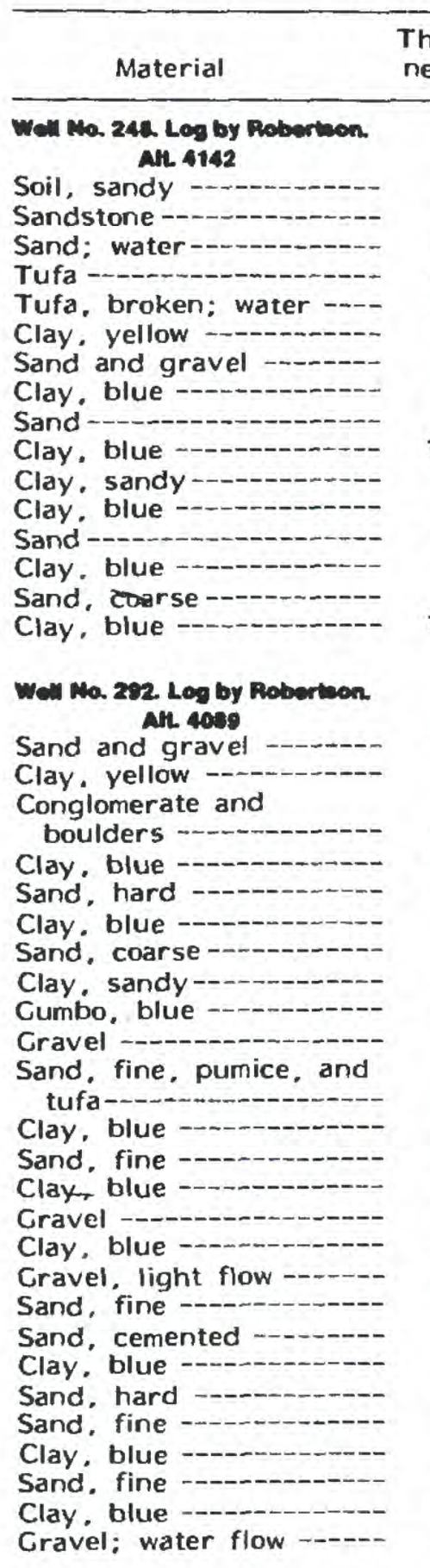

Thick-
ness Depth

$\begin{array}{rr}6 & 6 \\ 5 & 11 \\ 87 & 98 \\ 82 & 180 \\ 21 & 201 \\ 5 & 206 \\ 15 & 221 \\ 9 & 230 \\ 7 & 237 \\ 185 & 422 \\ 10 & 432 \\ 18 & 450 \\ 25 & 475 \\ 5 & 480 \\ 10 & 490 \\ 112 & 602\end{array}$

$48 \quad 48$

52

4496

$52 \quad 148$

$40 \quad 188$

190

200

240

262

265

284

292

345

350

362

390

408

433

436

442

447

459

464

486

490

500

\section{Well Ma. 21s. Leg by Robertwon.} AM 3900

Soil and sand

Gravel; water -...-........

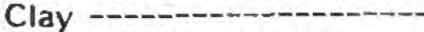

Rock, black, broken----

Rock. black, solid -..--

Rock, black, broken----

Rock, black, solid -----.

Rock, black, broken ----

Rock. black, solid -

Rock, red, broken -....-

Rock, red, solid -.....-

Rock, black, solid -..--

\section{Well Ma. 355. Log by Robertion.} AH. 347

Soil top -

Clay and cinders -...-..-

Rock, black, fractured--

Cinders, red and

black, with sand and

clay streaks -..--.....

Clay, brown and gray.

with sand streaks -

Cinders, red-..--

and blue, and black

sand streaks -.......-

Cinders -...................

Cinders, coarse, sand.

and clay -.-...-.

\begin{tabular}{|c|c|c|}
\hline Material & $\begin{array}{l}\text { Thick- } \\
\text { ness }\end{array}$ & Depth \\
\hline \multicolumn{3}{|l|}{ Well Mo. 355-Conlinued } \\
\hline $\begin{array}{l}\text { Clay, blue and brown, } \\
\text { with sand streaks ---- }\end{array}$ & 41 & 150 \\
\hline $\begin{array}{l}\text { Clay, brown, cinders, } \\
\text { with sand streaks - }\end{array}$ & 7 & 157 \\
\hline $\begin{array}{l}\text { Clay, brown and blue, } \\
\text { with sand streaks - }\end{array}$ & 15 & 172 \\
\hline $\begin{array}{l}\text { Rock, black, fractured, } \\
\text { with sand and clay }\end{array}$ & 3 & 175 \\
\hline $\begin{array}{l}\text { Rock, black, fractured, } \\
\text { and cobbles with sand } \\
\text { and clay }\end{array}$ & 5 & 180 \\
\hline $\begin{array}{l}\text { Rock, black, fractured, } \\
\text { and sand- }\end{array}$ & 20 & 200 \\
\hline $\begin{array}{l}\text { Rock, black, fractured, } \\
\text { and clay - }\end{array}$ & 22 & 222 \\
\hline $\begin{array}{l}\text { Sand, some clay } \\
\text { streaks }\end{array}$ & 21 & 243 \\
\hline Clay, blue, sticky - & 30 & 273 \\
\hline
\end{tabular}

Well Ma. 62. Log by J.R. Kittrell.

Soil -.. All 3250

Clay, red, and

embedded gravel ------

Sand dry -.--_-_-----

Conglomerate--..--

Gravel, coarse --

brown---..-...

Gravel, coarse, and

boulders -

Clay, hard, silty.

yellow--.-- $\quad 89 \quad 230$

Sand coarse, and

small gravel-an $19 \quad 249$

Conglomerate, sand, and clay-----c-n

Clay, hard, silty and

embedded gravel -

Sand, coarse, and

gravel

and hard - sily,

Sand, cemented, and

gravel -.......-

boulders -...............

Cravel, good, and

boulders -..-- clay.

Conglomerate. clay

Gravel, good

Sand. fine -..-.--

Well Ma. 346. Log by J.D. Hell.

\section{Ale. 3759}

Soil, top -

Clay

Sand and gravel -.------

Clay, sandy, and large

gravel -

Boulders, large -.....-

Clay, sandy, and small
boulders

Sand and gravel -.---.

Sand to large gravel:

water -ay, sandy, and

brown gravel-...-..-

Clay, sandy, red, and

gravel -

Sand. coarse; water

water -....--

Sand and small

boulders -..--

Clay, sandy, and

gravel - gravel:

water $021 \quad 275$
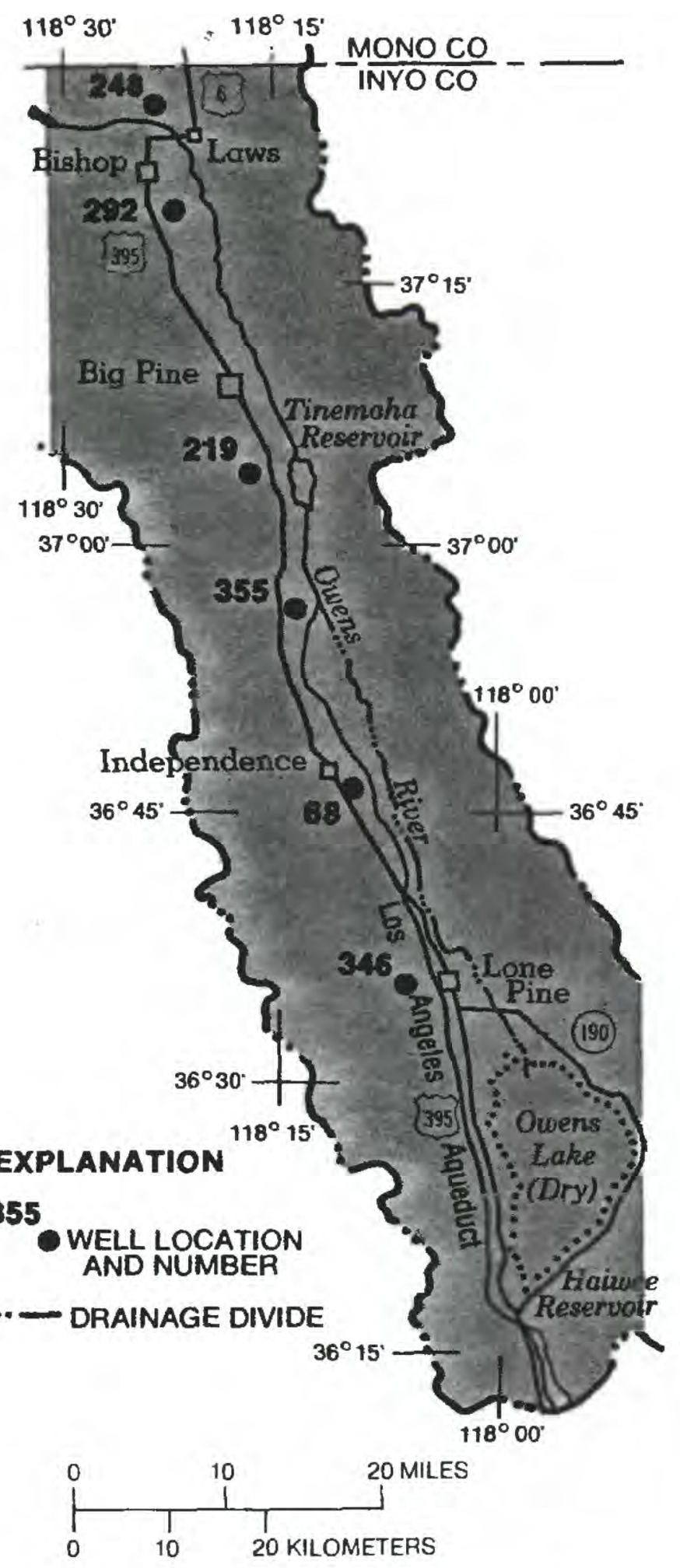

\begin{tabular}{|c|c|c|}
\hline Material & $\begin{array}{l}\text { Thick- } \\
\text { ness }\end{array}$ & Dept \\
\hline \multicolumn{3}{|l|}{ Well Na. 346-Continued } \\
\hline $\begin{array}{l}\text { Clay, sandy and gravel, } \\
\text { and decomposed } \\
\text { granite- }\end{array}$ & 28 & 303 \\
\hline $\begin{array}{l}\text { Clay. sandy, } \\
\text { decomposed granite, } \\
\text { and boulders }\end{array}$ & 19 & 322 \\
\hline $\begin{array}{l}\text { Sand to boulders } \\
\text { Clay, sandy, and }\end{array}$ & & 340 \\
\hline boulders - & 8 & 348 \\
\hline \multicolumn{3}{|l|}{$\begin{array}{l}\text { Sand and decomposed } \\
\text { granite. gravel, and }\end{array}$} \\
\hline little clay & 16 & 364 \\
\hline $\begin{array}{l}\text { Sand and decomposed } \\
\text { granite- }\end{array}$ & 17 & 381 \\
\hline $\begin{array}{l}\text { Clay, sandy, and } \\
\text { gravel }\end{array}$ & 2 & 383 \\
\hline $\begin{array}{l}\text { Sand and gravel } \\
\text { Clay. sandy, and }\end{array}$ & 32 & 415 \\
\hline & 3 & 418 \\
\hline $\begin{array}{l}\text { Sand to large gravel --- } \\
\text { Clay, sandy to }\end{array}$ & 6 & 424 \\
\hline & 6 & 430 \\
\hline
\end{tabular}

FIGURE 5.1-1.-Selected drillers' logs and location of wells. 


\title{
5.0 GROUND WATER--Continued
}

5.2 Recharge, Discharge, and Movement

\section{Ground Water Flows Southward from Bishop Toward Owens Lake}

\author{
Recharge of aquifers is primarily from infiltration of streamflow along flanks of \\ the Sierra Nevada.
}

Ground water in the valley is primarily from infiltration of streamflow along the flanks of the Sierra Nevada. Other sources include precipitation on the valley floor, underflow to the aquifer in the northern part of the valley, leakage from the Owens River and other water courses, controlled water spreading on the alluvial fans, releases of aqueduct water on the valley floor, and infiltration of water from irrigated fields.

Discharge occurs as springflow; evapotranspiration by vegetation; evaporation from open-water surfaces such as ditches, streams, rivers, and lakes; and by pumping of wells or free flow from artesian wells.

Ground-water movement occurs because of a downward slope or gradient toward discharge areas. Ground-water movement is relatively slow, ranging from a few feet to hundreds of feet per year. Although a particle of water in the Owens River would take about 8 hours to flow from Bishop to Tinemaha
Reservoir, it would require about 1,000 years to move the same distance through the valley-fill deposits.

Ground water moves from the flanks of the Sierra Nevada toward the center of the valley, and then southward from Bishop toward Owens Lake (dry). Some ground water discharges from the aquifers as evapotranspiration, springflow, and by flowing and pumping wells. In the central part of the valley, ground water naturally moves upward through the clay layers from the deep, confined aquifers to the near surface, unconfined aquifer.

The direction of ground-water movement in the deep and shallow aquifers can be inferred from contour lines representing equal altitudes of the water levels in wells. A three-dimensional representation of this potentiometric surface is shown using computer graphics (fig. 5.2-1). The flow path of the ground water is indicated by arrows which are perpendicular to the water-level contours of the lower map. 


\section{EXPLANATION}

- 3800 - POTENTIOMETRIC CONTOUR-Shows altitude at which * water level would have stood in 1982 in tightly cased wells tapping the confined aquifer. Contour interval, 100 feet. National Geodetic Vertical Datum of 1929

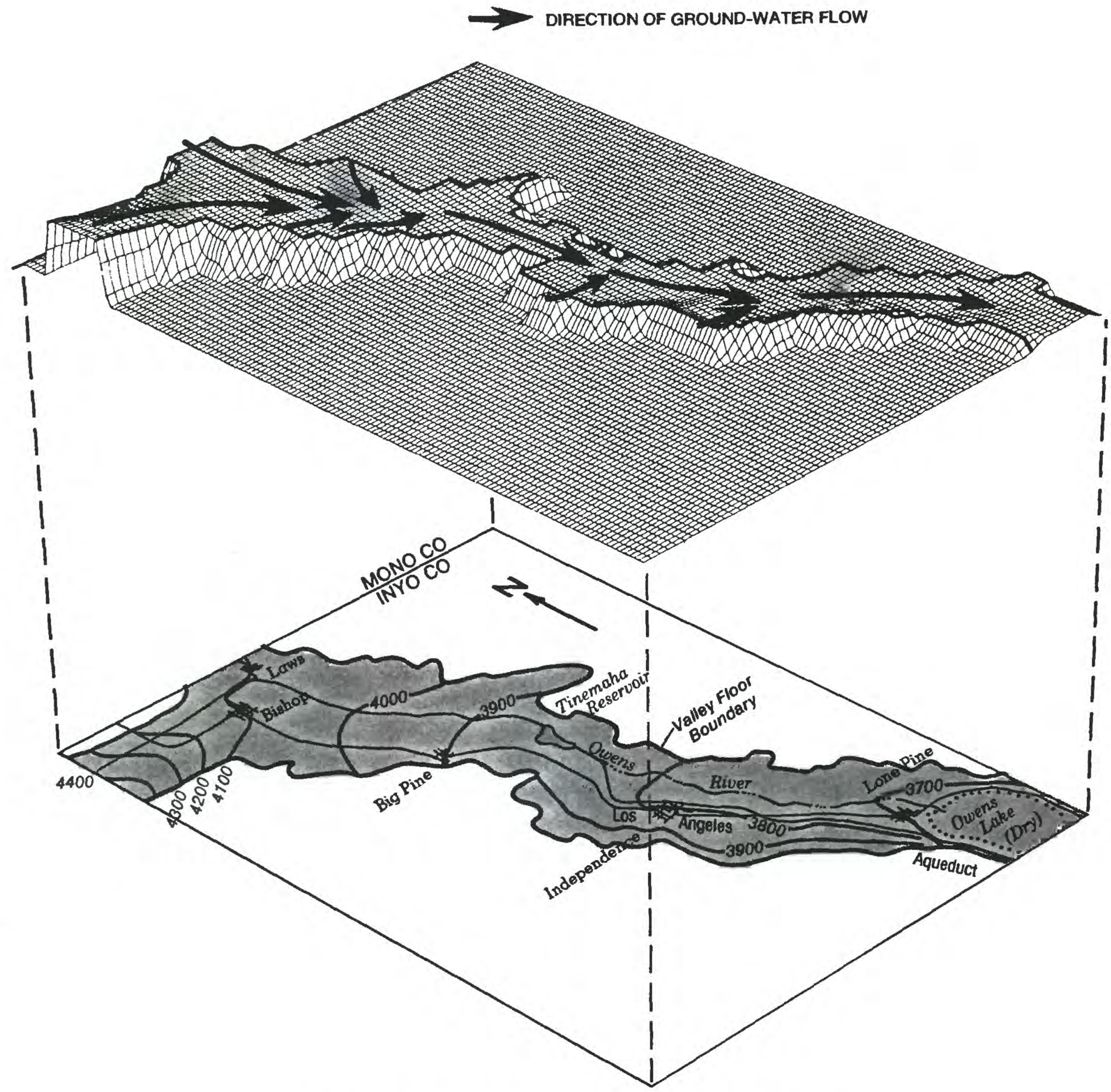

FIGURE 5.2-1.-Direction of grouud-water movement in the deep aquifers. 


\title{
5.0 GROUND WATER--Continued
}

\section{$5.3 \mathrm{Wells}$}

\section{Wells Supply Water for In-Valley Use and Export}

\author{
Pumpage from more than 90 pump-equipped wells averaged about 98,000 acre-feet \\ per year from 1971-83.
}

Pumpage of ground water in the valley is monitored by Los Angeles Department of Water and Power and Inyo County Water Department. Water levels are measured either monthly or semiannually in more than 500 shallow and deep wells, with continuous measurements on selected observation (nonpumping) wells. Pumping or flow rates from each pumped or flowing well are measured. Many of these ground-water data are computerized, tabulated, and stored monthly.

The first wells drilled by Los Angeles in 1908 were flowing wells located east of Independence. Many more flowing wells have been drilled since 1908. From 1925 to 1982 , the annual discharge from flowing wells generally ranged from 5,000 to 10,000 acre-feet per year. Prior to 1937, the total discharge from flowing wells was generally less than 5,000 acre-feet per year, in part, due to the fewer number of flowing wells (fig. 5.3-1).

In 1917, the first pump was installed in a well, and ground-water pumpage supplemented the discharge from flowing wells. From 1908 to 1970, Los Angeles drilled about 350 wells in Owens Valley. Most of the wells drilled ranged in depth between 100 and 600 feet and were located on the valley floor. Each of these wells typically yielded 1,000 to 5,000 gallons per minute of water. As of 1979, Los Angeles had about 475 wells and test holes on city-owned land in Owens Valley. More than 90 of these wells are equipped with pumps for extracting ground water (Los Angeles Department of Water and Power, 1978, p. 5-7 to 5-8). Pumpage from these wells averaged about 98,000 acre-feet per year for 1971-83, but was generally less than 10,000 acre-feet per year from 1932 to 1970 , except during dry years (fig. 5.3-1).

Pump-equipped wells are generally located on the west side of the valley and were drilled along lines perpendicular to the ground-water flow pattern in order to intercept a large percentage of water flowing across the valley. This grouping of wells in a particular area is referred to as a well field. The approximate extent of the well field for each area is shown in figure 5.3-2. Average pumpage for each well field is shown in table 5.3-1. The Big Pine-Crater Mountain and Taboose-Aberdeen well fields supply about 50 percent of the total pumpage in Owens Valley.

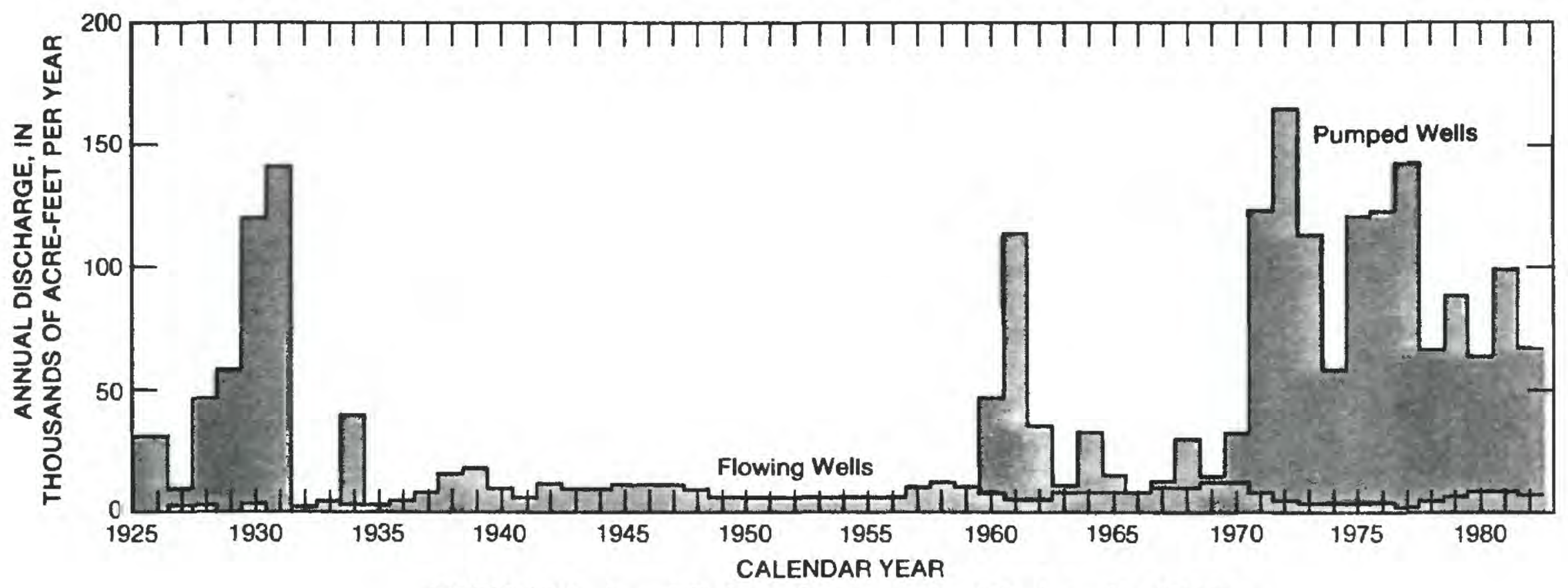

FIGURE 5.3-1.- Annual discharge from pumped and flowing wells, 1925-82.

(Data from Los Angeles Department of Water and Power.) 


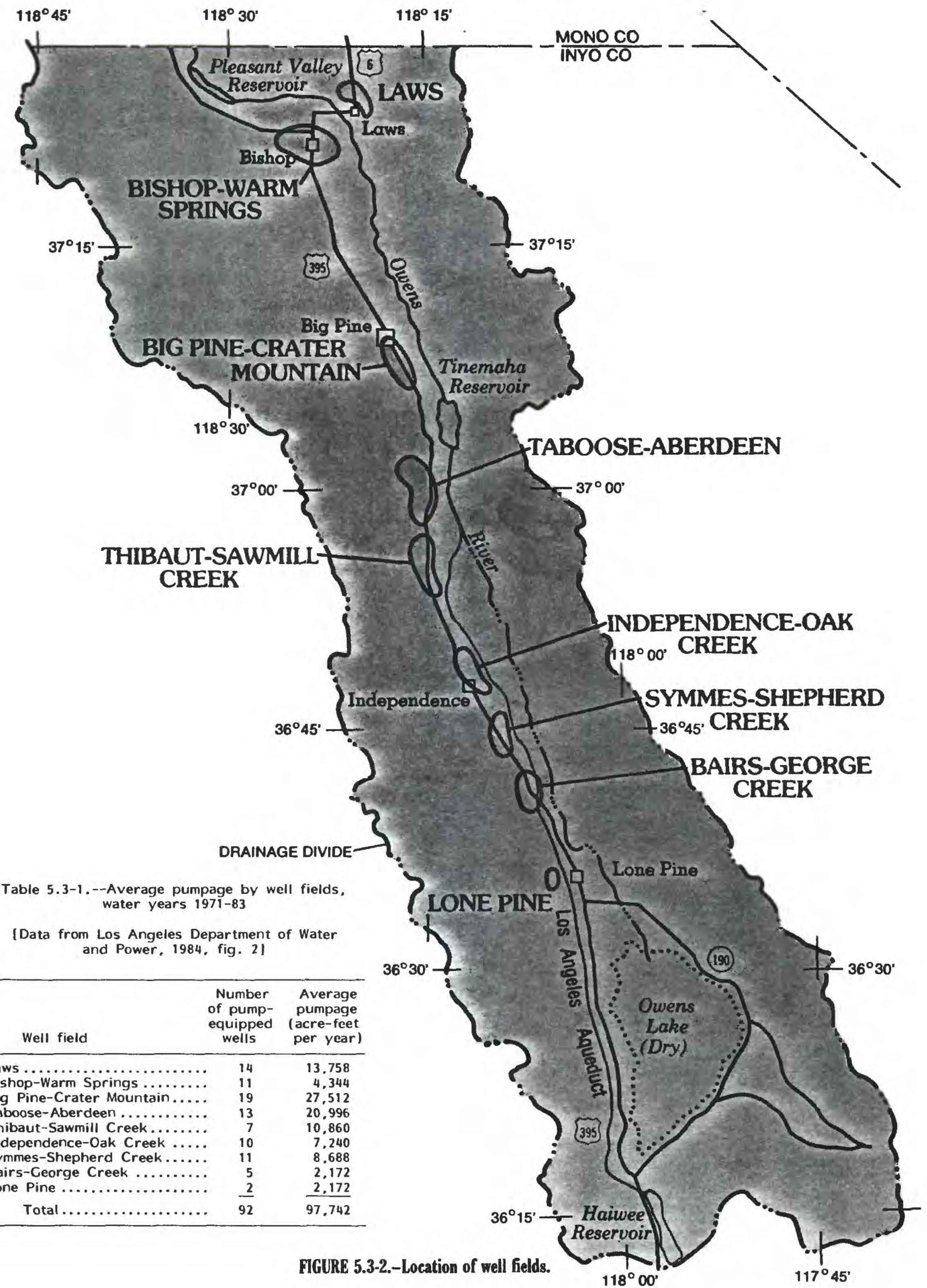

5.0 GROUND WATER--Continued 


\subsection{GROUND WATER--Continued}

5.4 Springs

\section{Springs Discharge Large Quantities of Water}

Springflow is directly affected by pumping in nearby wells.

Historically, springs between Big Pine and Independence discharged the largest quantities of water in Owens Valley. These springs are Fish, Big Seeley, Little Seeley, Hines, Little Blackrock, and Big Blackrock (fig. 5.4-1). Springflow and pumpage data for 1935-84 are shown for two representative springs in figure 5.4-2. A direct and immediate effect was measured on the quantity of springflow when nearby deep wells were pumped (Los Angeles Department of Water and Power, 1978, Appendix 6). Springs ceased to flow with continued pumping, and flowed again when pumping ceased or was minimal.

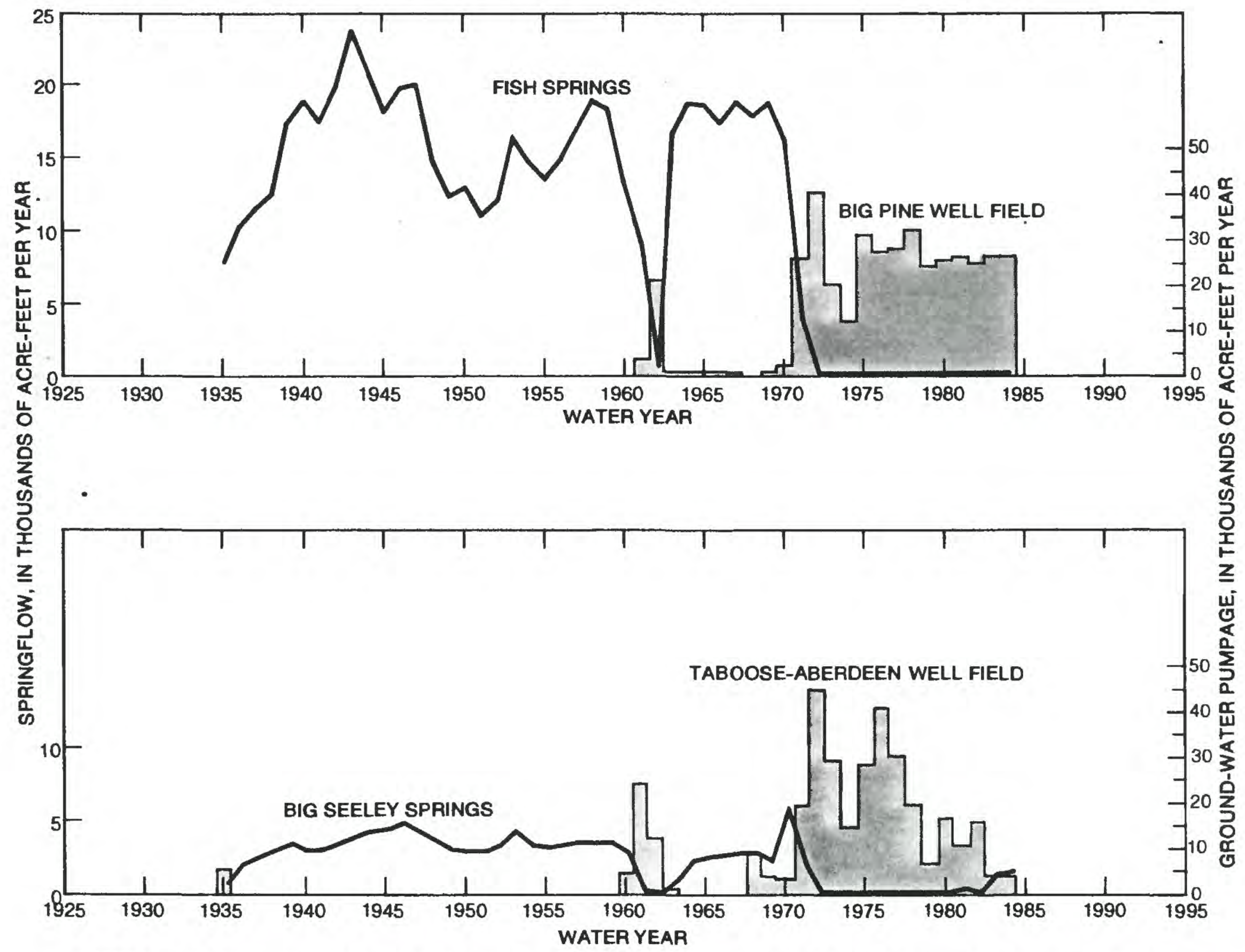

FIGURE 5.4-2.- Comparison of springflow (lines) and ground-water pumpage (bars) for two representative springs, 1935-84. 


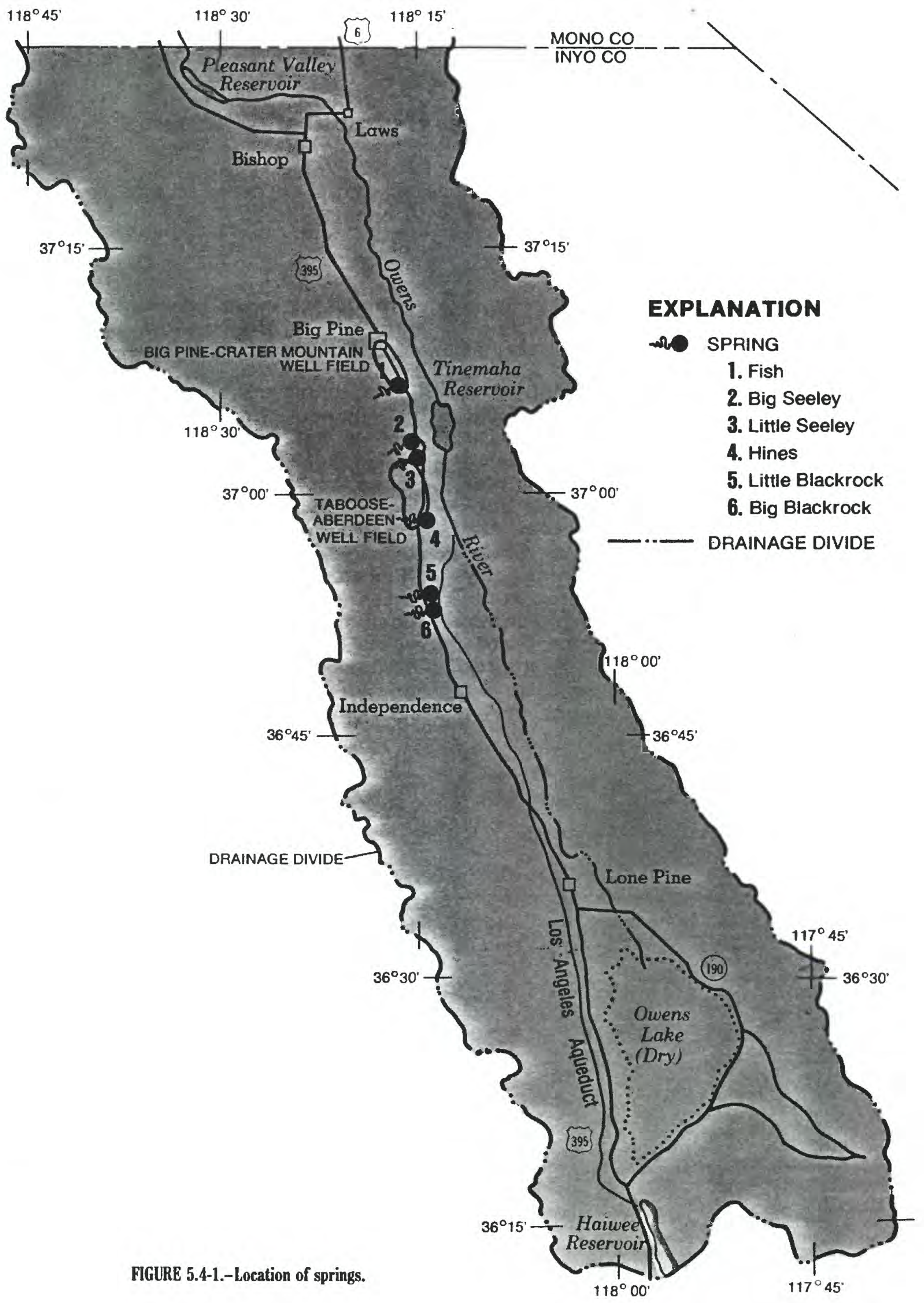

5.0 GROUND WATER--Continued 5.4 Springs 


\subsection{GROUND WATER--Continued}

\section{Deep and Shallow Aquifers Hydraulically Connected}

Pumping from a deep aquifer can have markedly different effects on the shallow aquifer.

Most ground-water pumping historically has been from deep aquifers. As shown in the diagrammatic section in figure 5.5-1, the effects of pumping from a deep aquifer can vary markedly. If pumpage from a deep aquifer is large enough, the potentiometric surface of the deep aquifer is lowered to a level below the water table in the shallow aquifer (case a). Where the potentiometric surface of the deep aquifer is below the water table, ground water moves downward slowly through the confining clay layer from the shallow to the deep aquifer. If pumping from the deep aquifer is not great enough to lower the potentiometric surface of the deep aquifer to a level below the water table in the shallow aquifer (case b), ground water continues to move upward from the deep aquifer into the shallow aquifer but at a slower rate.

The conditions and processes that control changes in water levels and movement of water between aquifers in Owens Valley--such as the nature and thickness of the confining layers, evapotranspiration at the land surface, the quantities of ground-water recharge, and the pumpage from each aquifer--are not fully understood. These conditions and processes are the subject of a series of ongoing comprehensive ground-water and vegetation studies being done by the U.S. Geological Survey, Inyo County, and Los Angeles Department of Water and Power. 


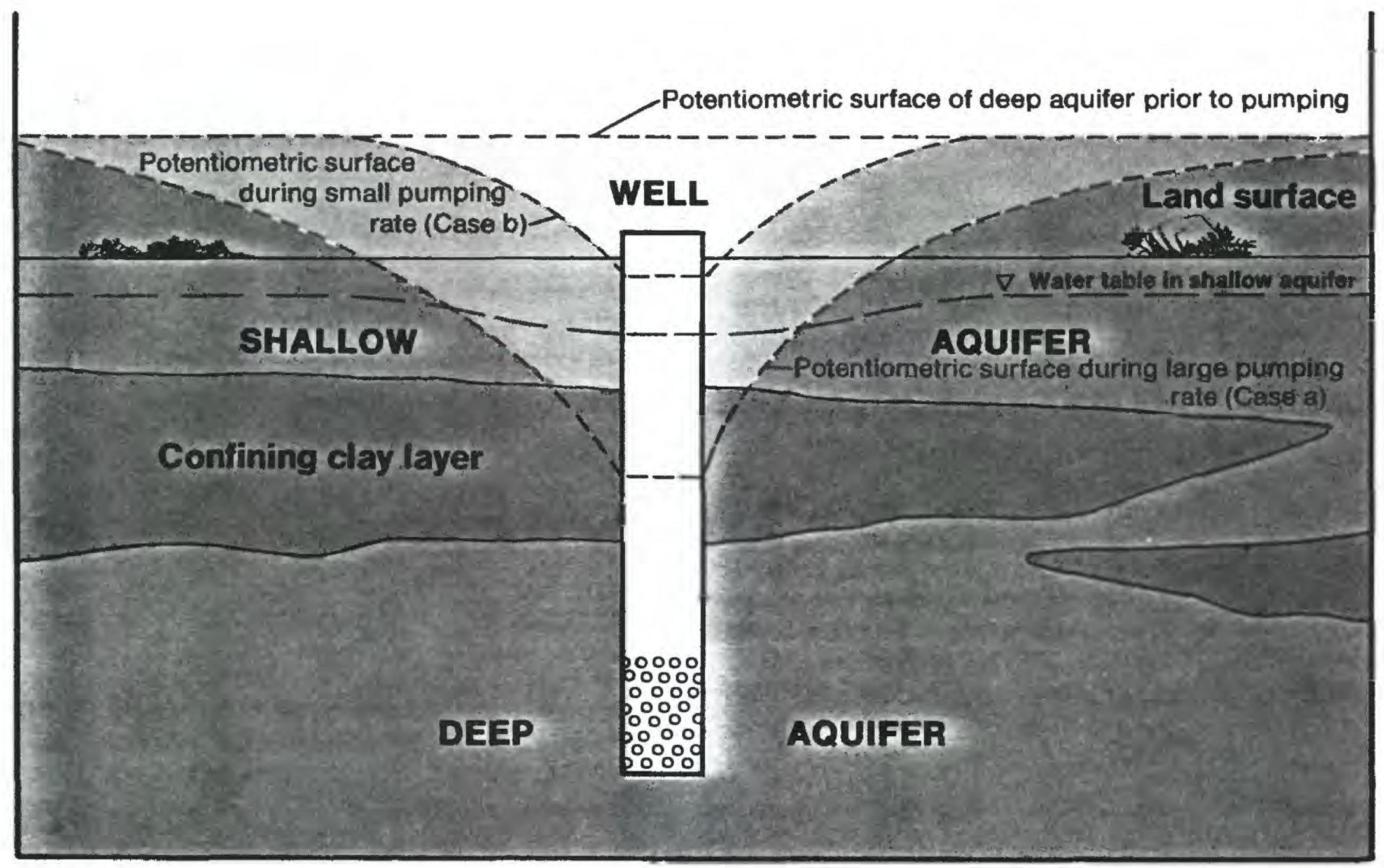

FIGURE 5.5-1.-Diagrammatic section showing drawdown of potentiometric surface created by different rates of pnmping from a well that taps a deep aquifer. 


\title{
5.0 GROUND WATER--Continued
}

5.6 Historical Water-Level Fluctuations, 1971-84

\section{Water Levels Vary in Deep and Shallow Wells}

\author{
In general, there is some correlation between ground-water pumpage and \\ water-level fluctuations.
}

Historically, water levels measured in wells that tap deep and shallow aquifers vary depending on the thickness and extent of aquifers and intervening clay layers; transmission and storage properties of the aquifers; quantities of recharge, evapotranspiration, and pumpage; depth and location of perforated sections of wells; and pumping duration. An increase or decrease in ground-water pumping correspondingly creates a decline or rise in the water level in the pumping well and other wells in the vicinity. with some time delay. The decline of water levels in deep and shallow wells is not an irreversible occurrence, because when pumping is discontinued, water levels generally recover to their previous level after a period of time.

Measured water levels for selected deep and shallow wells and ground-water pumpage for five of the nine well fields are shown in figure 5.6-1. Water-level fluctuations in deep wells indicate a direct correlation with ground-water pumpage. In many well fields. there is also some correlation between pumping in deep wells and water-level fluctuations in nearby shallow wells. Fluctuations in shallow wells, however, also are affected by changes in evapotranspiration and precipitation. The cause-and-effect relation of water-level fluctuations in deep and shallow wells is not well understood and is the subject of current studies.

In the Laws well field, ground-water pumping is primarily from the deep and shallow parts of the saturated valley-fill deposits. Long-term water-level trends generally are similar in the deep and shallow wells in the Laws well field because of the lack of extensive clay layers between the deep and shallow aquifers. Similar conditions exist in the south and southwest parts of the Bishop-Warm Springs well field (not shown), and waterlevel fluctuations are similar to those measured in the Laws well field. However, in the east and west parts of the Bishop-Warm Springs well field, water-level trends in the deep and shallow aquifers do not correlate well.

Big Pine-Crater Mountain and TabooseAberdeen well fields supply about 50 percent of the total pumpage in Owens Valley. Ground-water pumping is primarily from deep aquifers in or near the volcanic rocks. Wells completed in the volcanic rocks yield large quantities of ground water. About two-thirds of the pumpage from the Big Pine-Crater Mountain well field is from wells near Fish Springs, which are about 0.5 mile southwest of well 224, for which the change in water levels is shown in figure 5.6-1.

Well Data

[Altitude of land surface in feet above NGVD of 1929]

\begin{tabular}{|c|c|c|c|c|c|c|c|c|c|c|c|}
\hline \multirow[b]{2}{*}{$\begin{array}{l}\text { Well } \\
\text { No. }\end{array}$} & \multicolumn{2}{|c|}{${ }^{\star}$ Depth (feet) } & \multirow[b]{2}{*}{ Altitude } & \multicolumn{3}{|c|}{${ }^{*}$ Depth (feet) } & \multirow[b]{2}{*}{ Altitude } & \multirow[b]{2}{*}{$\begin{array}{l}\text { Well } \\
\text { No. }\end{array}$} & \multicolumn{2}{|c|}{${ }^{*}$ Depth (feet) } & \multirow[b]{2}{*}{ Altitude } \\
\hline & Total & $\begin{array}{l}\text { Perfor- } \\
\text { ated }\end{array}$ & & $\begin{array}{l}\text { Well } \\
\text { No. }\end{array}$ & Total & $\begin{array}{l}\text { Perfor- } \\
\text { ated }\end{array}$ & & & Total & $\begin{array}{l}\text { Perfor- } \\
\text { ated }\end{array}$ & \\
\hline & \multicolumn{3}{|c|}{ Laws } & \multicolumn{4}{|c|}{ Big Pine-Crater Mountain } & \multicolumn{4}{|c|}{ Taboose-Aberdeen } \\
\hline $\begin{array}{l}271 \\
436 T\end{array}$ & $\begin{array}{r}113 \\
21\end{array}$ & $\begin{array}{l}91-111 \\
19-21\end{array}$ & $\begin{array}{l}4,126.0 \\
4,106.3\end{array}$ & $\begin{array}{l}224 \\
425 \mathrm{~T}\end{array}$ & $\begin{array}{r}* \star 322 \\
42\end{array}$ & $\begin{array}{l}96-114 \\
40-42\end{array}$ & $\begin{array}{l}3,879.4 \\
3,880.7\end{array}$ & $\begin{array}{l}160 \\
419 T\end{array}$ & $\begin{array}{l}90 \\
29\end{array}$ & $\begin{array}{r}\text { unknown } \\
27-29\end{array}$ & $\begin{array}{l}3,873.9 \\
3,834.0\end{array}$ \\
\hline
\end{tabular}

* Drilled or jetted.

** Open hole 114-322 feet. 

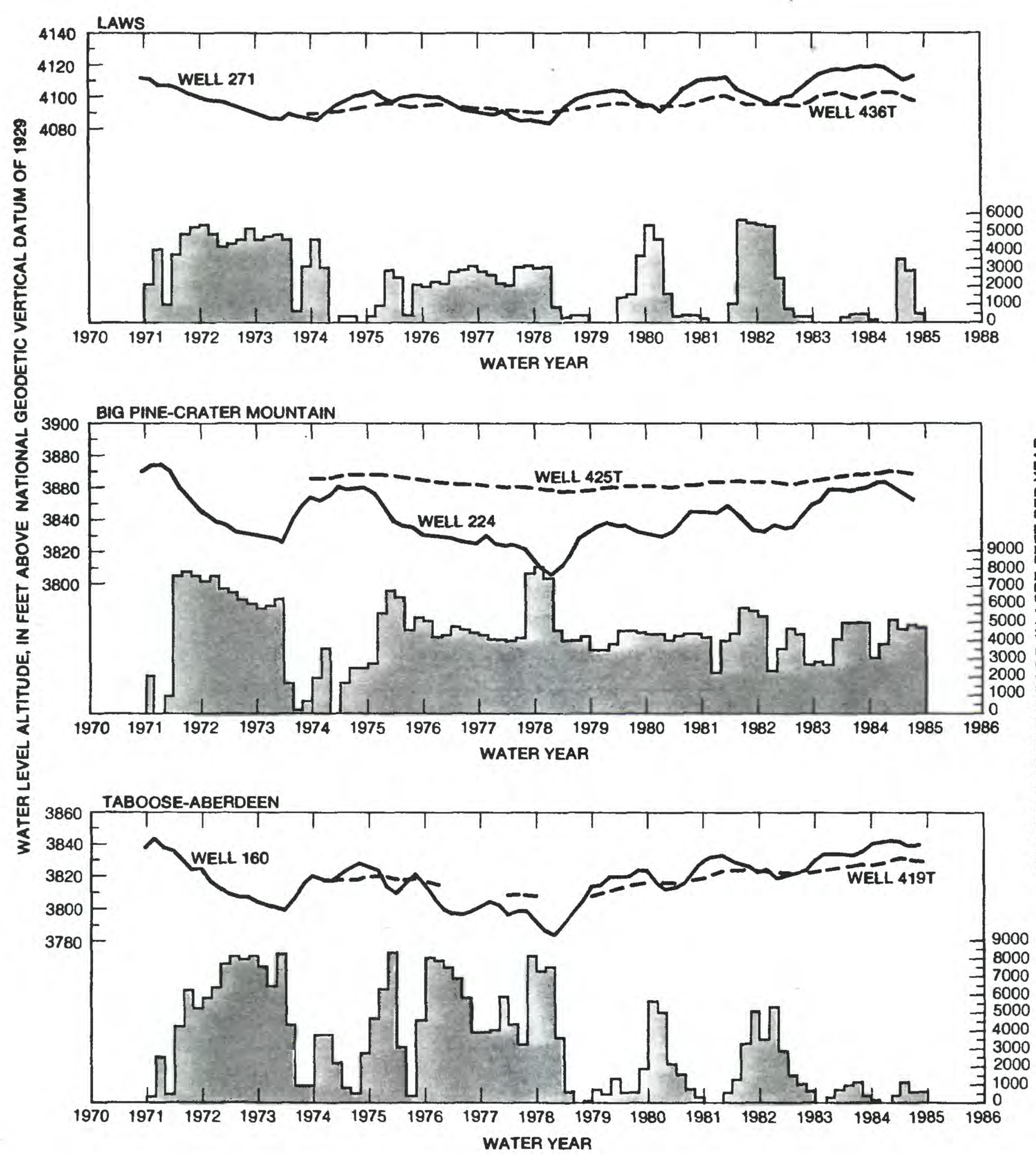

\section{EXPLANATION}

WATER LEVEL

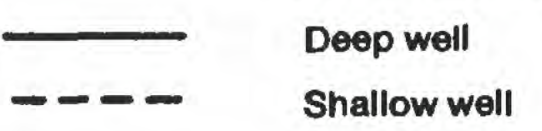

TrI GROUND-WATER PUMPAGE

FIGURE 5.6-1.-Measured water levels for selected deep and shallow wells and ground-water punpage for five well fields, water years 1971-84.

\subsection{GROUND WATER--Continued}

5.6 Historical Water-Level Fluctuations, 1971-84 


\subsection{GROUND WATER--Continued \\ 5.6 Historical Water-Level Fluctuations, 1971-84--Continued}

In the Thibaut-Sawmill Creek well field, ground-water pumping is primarily from the volcanic rocks. Deep well 356 and shallow well $416 \mathrm{~T}$ are less than 0.25 mile apart. About three-fourths of the pumpage from this well field is from well 356 and an adjacent well. When these wells are pumped, Blackrock Springs, which produces water from the volcanic rocks, ceases to flow. The pumping of deep well 356, which caused a water-level decline in 1984 of 30 feet, had minimal effect on the water level in nearby shallow well 416 $\mathrm{T}$, except during increased pumping in late 1980. In 1984, however, the water level in the shallow well $416 \mathrm{~T}$ rose when the water level in deep well 356 declined.
In the Independence-Oak Creek, SymmesShepherd Creek, Bairs-George Creek, and Lone Pine well fields (the latter three not shown), wells are perforated in both the deep and shallow aquifers. Athough pumpage is principally from the deep aquifers, some pumpage is also contributed by the shallow aquifers. In these well fields, pumping has been minimal since 1978, and higher than normal runoff has caused a rise in water levels. Water-level trends in the SymmesShepherd Creek, Bairs-George Creek, and Lone Pine well fields are similar to those measured in Independence-Oak Creek well field (fig. 5.6-1).

Well Data

[Altitude of land surface in feet above NGVD of 1929]

\begin{tabular}{|c|c|c|c|c|c|c|c|}
\hline \multirow[b]{2}{*}{$\begin{array}{l}\text { Well } \\
\text { No. }\end{array}$} & \multicolumn{2}{|c|}{ *Depth (feet) } & \multirow[b]{2}{*}{ Altitude } & \multirow[b]{2}{*}{$\begin{array}{l}\text { Well } \\
\text { No. }\end{array}$} & \multicolumn{2}{|c|}{${ }^{*}$ Depth (feet) } & \multirow[b]{2}{*}{ Altitude } \\
\hline & Total & $\begin{array}{l}\text { Perfor- } \\
\text { ated }\end{array}$ & & & Total & $\begin{array}{c}\text { Perfor- } \\
\text { ated }\end{array}$ & \\
\hline & \multicolumn{3}{|c|}{ Thibaut-Sawmill Creek } & \multicolumn{3}{|c|}{ Independence-Oak } & Creek \\
\hline $\begin{array}{l}356 \\
416 T\end{array}$ & $\begin{array}{r}160 \\
23\end{array}$ & $\begin{array}{l}50-110 \\
21-23\end{array}$ & $\begin{array}{l}3,824.7 \\
3,812.8\end{array}$ & $\begin{array}{l}35 \\
408 T\end{array}$ & $\begin{array}{r}230 \\
21\end{array}$ & $\begin{array}{r}\text { unknown } \\
19-21\end{array}$ & $\begin{array}{l}3,838.4 \\
3,807.0\end{array}$ \\
\hline
\end{tabular}

*Drilled or jetted. 


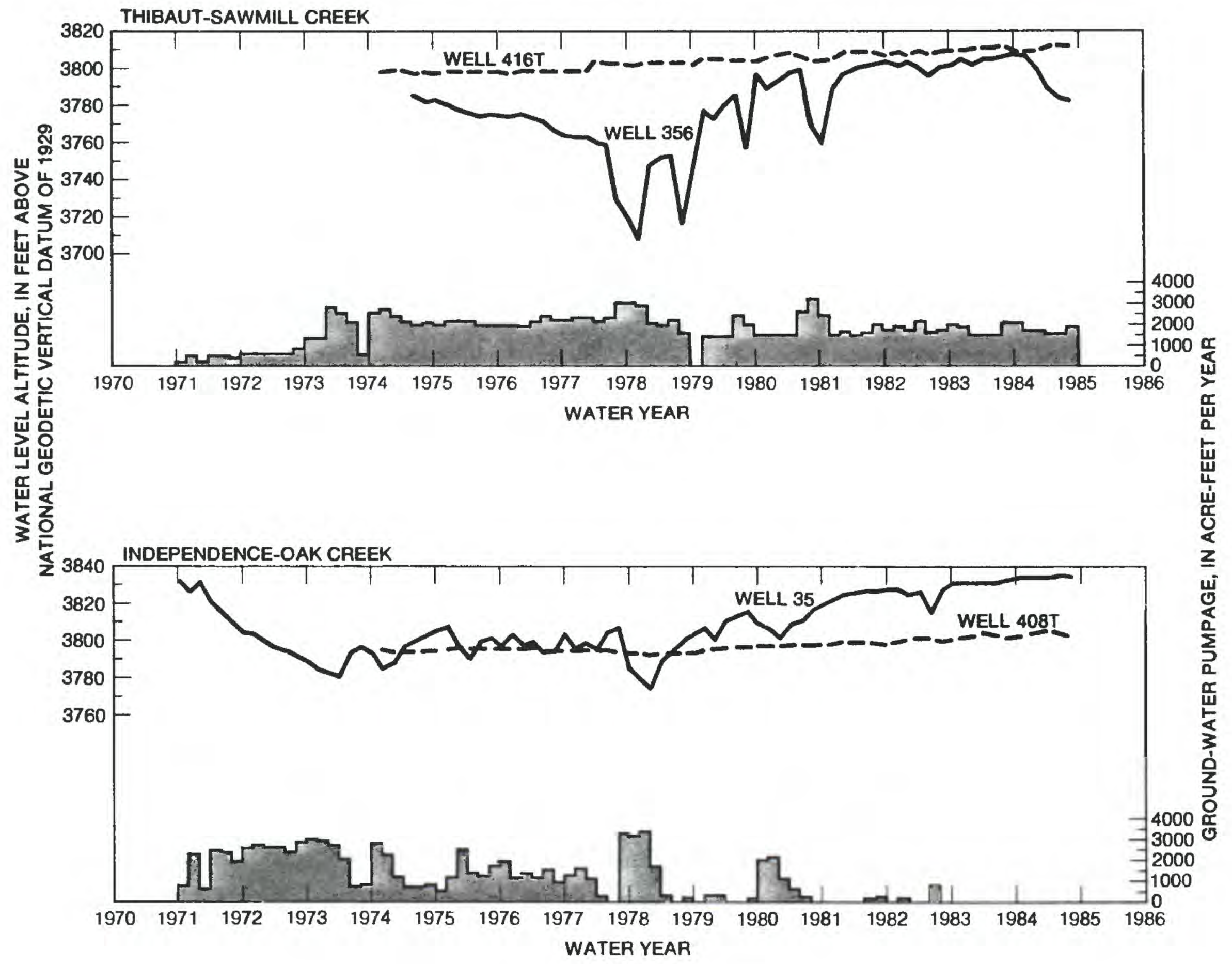

EXPLANATION

WATER LEVEL

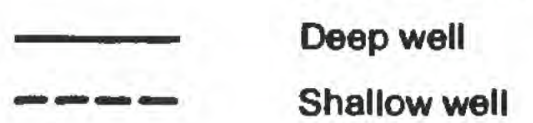

H.u GROUND-WATER PUMPAGE

FIGURE 5.6-1.- Measured water levels for selected deep and shallow wells and ground-water pumpage for five well fields, water years 1971-84 --Continned. 


\title{
6.0 ADDITIONAL STUDIES
}

\section{Valleywide Water-Management Plan Being Studied}

\begin{abstract}
A multiple-agency, 5-year study will better define the quantity and availability of the ground water in the valley, as well as determine the effects of ground-water withdrawals on native vegetation.
\end{abstract}

Since October 1982, Inyo County and the city of Los Angeles have entered into agreements with the U.S. Geological Survey and with each other to conduct a 5-year study to define the ground-water characteristics of Owens Valley and to determine what effect ground-water withdrawals might have on native vegetation. The study is divided into three projects (fig. 6.0-1), each funded and administered separately for ease of organization and cortrol of study tasks.

The first project, a cooperative vegetation study, is administered jointly by Inyo County and the city of Los Angeles. The objective of this project is to map the plant distribution in the valley, relate plant physiology and distribution to changes in soil moisture and, in turn, the relation of soil moisture to changes in evapotranspiration. The results from this study will be used to calibrate and test plant water-use models and to help Inyo County and the city of Los Angeles develop a watermanagement plan.

The second project, administered by the Geological Survey, is a plantsurvivability study. The objective of the study is to quantify the relation between plant stress and survivability in relation to changes in shallow groundwater levels. Control sites have been established in four areas in the valley where regulated changes in shallow ground-water levels can be studied to relate the ability of native vegetation to survive under differing conditions of ground-water availability. The results from the plant-survivability study will be used as optimization/management constraints in the ground-water study.

The third project, also administered by the Geological Survey, is a ground-water study. Within the ground-water project. teams have been set up to (1) study the effects of local weather on evapotranspiration: (2) analyze the relation between soil moisture, plant stress, and evapotranspiration using mathematical modeling techniques (plant and wateruse model). The plant and water-use model is being developed by researchers at the University of California at Irvine and affiliated with the Geological Survey; and (3) analyze the ground-water flow system using mathematical models that integrate geologic and hydrologic boundary conditions, and simulate addition or subtraction of water from the system by evapotranspiration, wells, rivers, and recharge from snowmelt and precipitation.

The ultimate objective of the groundwater project is to analyze the groundwater system by using ground-water flow and optimization/management models. These models hopefully will be used to help the management agencies develop management alternatives that will attempt to optimize valley ground-water withdrawals. The constraints for groundwater withdrawal are dependent on plant-water requirements for survivability, available water from recharge and runoff, aqueduct water requirements for export, and ground water stored in the hydrologic system. 


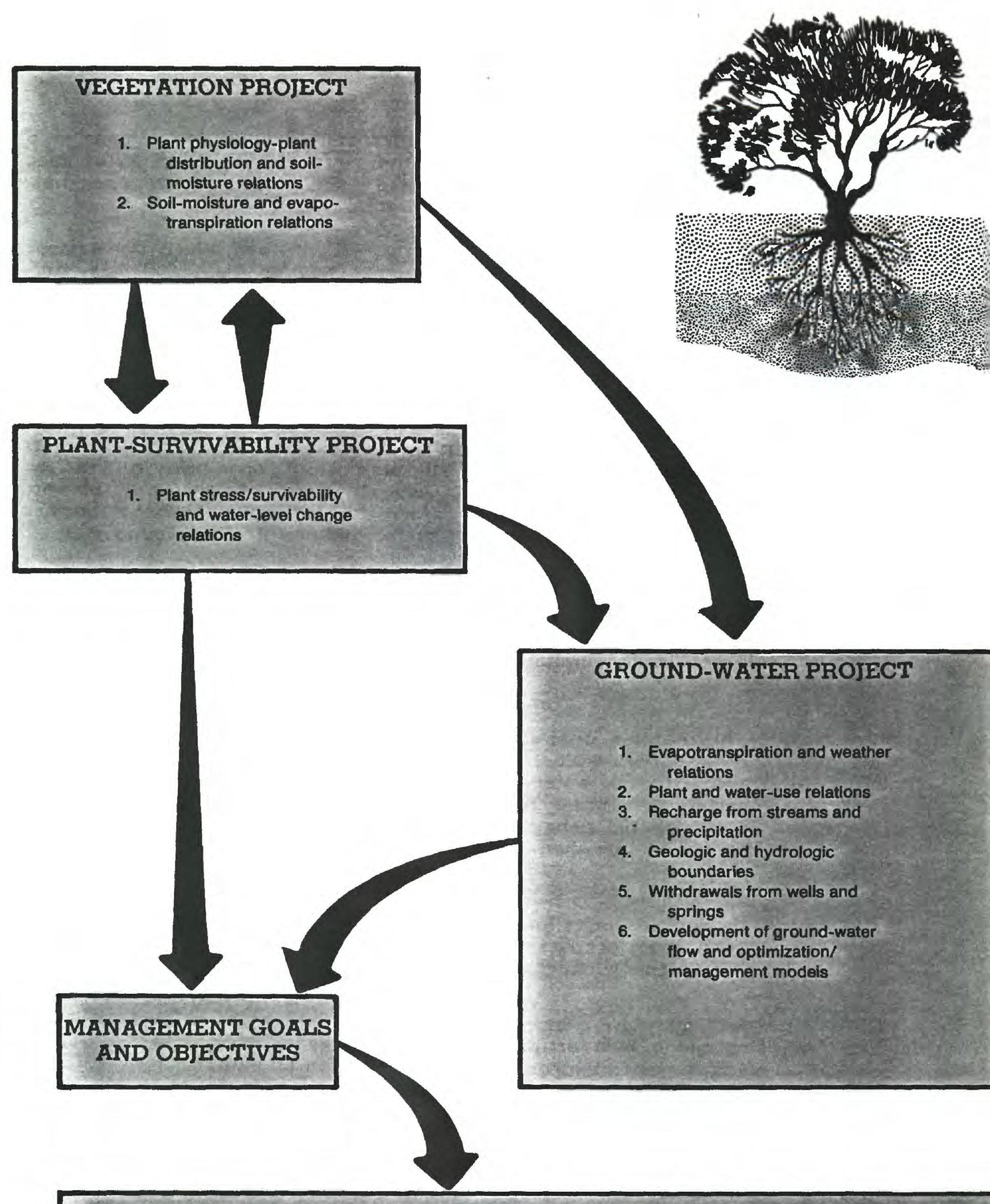

FIGURE 6.0-1.-0wens Valley ground-water and vegetation studies, October 1982 to September 1987. 


\subsection{GLOSSARY}

Acre-foot.--The quantity of water required to cover an area of 1 acre to a depth of 1 foot, equal to about 326,000 gallons. Used for measurement of large quantities of water.

Alluvial fan.--A low, outspreading, relatively flat to gently sloping mass of loose rock material at the foot of a mountain range, shaped like an open fan and deposited by a stream.

Aquifer.--A body of rock below the surface of the earth capable of storing and transmitting ground water and yielding significant quantities of water to wells and springs.

Arid climate.--Climate characterized by low rainfall and high evaporation potential. A region is usually considered as arid where an average of less than 10 inches of precipitation occurs per year.

Confined aquifer.--An aquifer that lies between layers of less permeable rock materials in which ground water is confined under pressure. Water levels in nonpumping wells that penetrate a confined aquifer are higher than the top of the aquifer.

Confining clays.--Impervious or slightly pervious clay layers which restrict the movement of water in the subsurface.

Discharge.--The rate of flow, for instance, from a pumping well or of a stream, at a given moment, expressed as volume per unit of time; for example, acre-feet per year or cubic feet per second.
Evapotranspiration.--Water used by plants (transpiration) and water evaporated from soil and open-water surfaces.

Flowing well.--A well which penetrates a confined aquifer zone and has sufficient pressure to cause the water to rise and flow out of the well.

Graben.--An elongate depressed block that is bounded on at least two sides by faults.

Infiltration.--The movement of water through small openings in the soil. Generally refers to movement of water from the land surface or a body of surface water into the ground.

National Geodetic Vertical Datum (NGVD) of 1929--A geodetic datum derived from a general adjustment of the first-order level nets of both the United States and Canada, formerly called "Mean Sea Level."

Normal fault.--A fault in which the upper wall appears to have moved downward relative to the lower wall. The angle of this type of fault is usually 45 to 90 degrees.

Observation well.--A well drilled in a selected location for the purpose of observing water levels or for the collection of water samples for chemical analysis.

Playa.--The flat-floored bottom of an undrained desert basin that becomes a shallow lake at times of above average precipitation or runoff.

Permeability.--A measurement of the ability of aquifer material to transmit water. 
Potentiometric surface.--A surface that represents the height of the free surface of a body of water above a given subsurface point in an aquifer. It is defined by the level at which water will stand in a tightly cased well.

Pumping well.--A well that is equipped with a pump to bring water to the surface.

Rainshadow effect.--The weather effect in a region where on the lee side of a mountain or mountain range, facing away from the prevailing winds and storm track, the rainfall is noticeably less than on the windward side.

Recharge.--The processes involved in the addition of water to the groundwater system.

Unconfined aquifer.--An aquifer in which only part of the permeable rock is saturated and which has a water table.

Underflow.--Movement of water through subsurface stratum.

Water resources.--Supply of water in a given area of a drainage basin, usually interpreted in terms of availability of surface or underground water.
Water spreading.--Application of water to lands for the purpose of increasing the growth of vegetation or to store it as ground water for subsequent withdrawal; the diversion of surface runoff to allow it to infiltrate into the soil.

Water table.--The surface in an unconfined aquifer below which the materials are saturated with water. The water table is the level at which water stands in wells that penetrate the uppermost part of an unconfined aquifer. The water-table surface is at atmospheric pressure.

Water Year.--The 12-month period, October 1 through September 30. The water year is designated by the calendar year in which it ends and which includes 9 of the 12 months. Thus, the year ending September 1986 is called the 1986 water year.

Wells.--Generally cylindrical in form and often walled in, sunk (drilled, dug, driven, bored, or jetted) into the ground to such a depth as to penetrate water-yielding rock or soil usually for the purpose of allowing water to flow or to be pumped to the land surface. 


\subsection{SELECTED REFERENCES}

Bateman, Paul, and others, 1978, Deepest Valley, A guide to Owens Valley--its roadsides and mountain trails, Genny Schumacher Smith [ed.]. Revised edition 1978: Los Altos, California, William Kaufmann Inc. $233 \mathrm{p}$.

California Department of Water Resources, 1960. Reconnaissance investigation of water resources of Mono and Owens Basins: Mono and Inyo Counties, $92 \mathrm{p}$.

California Resources Agency, 1978, Comments on draft EIR. Increased pumping of the Owens Valley ground-water basin: [California] Department of Conservation memo of October 30, 1978, 1 p.: [California] Department of Fish and Game memo of November 8, 1978, 2 p.: [California] Department of Water Resources memo of December 6 , 1978, 9 p.: [California] Office of the Secretary memo of December 5, 1978, $2 \mathrm{p}$; [California] The Resources Agency of California, letter of December 6, 1978, 3 p.; [California] State Water Resources Control Board memo of October $30,1978,3 \mathrm{p}$.

Griepentrog, T.E., and Groeneveld, D.P., 1981, The Owens Valley Water Management Report: County of Inyo., 273 p.

Hardt, W.F., 1980, Review of hydrologic information for adequacy in developing a water-management plan in the Owens Valley. southern California. Appendix B of Owens Valley ground-water investigation, Phase 1: California Department of Water Resources Southern District report, $77 \mathrm{p}$.

Knopf, Adolph, 1918, A geologic reconnaissance of the Inyo Range and the eastern slope of the southern Sierra Nevada, California, with a section on the stratigraphy of the Inyo Range, by Edwin Kirk: U.S. Geological Survey Professional Paper 110, $130 \mathrm{p}$.

Lee, C.H., 1912, An intensive study of the water resources of a part of Owens Valley. California: U.S. Geological Survey WaterSupply Paper 294, 135 p.

Lee, W.T., 1906, Geology and water resources of Owens Valley. California: U.S. Geological Survey Water-Supply and Irrigation Paper 181, $28 \mathrm{p}$.
Lohman, S.W., and others, 1972, Definitions of selected ground-water terms--Revisions and conceptual refinements: U.S. Geological Survey Water-Supply Paper 1988, 21 p.

Los Angeles [City] Department of Water and Power, 1963, Proposed second barrel, Los Angeles aqueduct, Forecasts of water demand and future sources of supply, $138 \mathrm{p}$.

1966. Water supply management in Inyo and Mono Counties, 60 p.. 1 app.

1972. Report on water resources management plan. Owens Valley groundwater basin, $160 \mathrm{p}$.

1974. Ground-water quality in the Owens Valley. 1973, $88 \mathrm{p}$.

1978, Increased pumping of the Owens Valley ground-water basin: Draft Environmental Impact Report: City of Los Angeles, Department of Water and Power, 152 p., 8 app.

1979. Increased pumping of the Owens Valley ground-water basin: Final Environmental Impact Report, v. 2, 125 p., app. and technical supplement.

1984. Owens Valley groundwater conditions--Update, $29 \mathrm{p}$.

Pakiser, L.C., Kane, M.F., and Jackson, W.H. 1964, Structural geology and volcanism of Owens Valley region, California-A geophysical study: U.S. Geological Survey Professional Paper 438, $68 \mathrm{p}$.

Stoddard and Karrer, 1964, Plans of the City of Los Angeles to construct the second barrel of Los Angeles aqueduct and increase diversions from the Mono and Owens basins: Los Banos, California, Stoddard and Karrer, 25 p.

Williams, D.E., 1969, Preliminary geohydrologic study of a portion of the Owens Valley ground-water reservoir: New Mexico Institute of Mining and Technology, unpub. Ph.D. thesis, $194 \mathrm{p}$. 